\title{
Triassic palynoevents in the circum-Arctic region
}

\author{
Gunn Mangerud ${ }^{1^{*}}$, Niall W. Paterson ${ }^{2}$ and Jonathan BujaK ${ }^{3}$ \\ 1. Department of Earth Science, University of Bergen, Allégaten 41, N-5007 Bergen, Norway \\ 2. CASP, West Building, Madingley Rise, Cambridge, CB3 0UD, UK \\ 3. Bujak Research (International), 114 Abbotsford Road, Blackpool, Lancashire FY3 9RY, UK \\ *Corresponding author: <gunn.mangerud@uib.no>
}

Date received: 2 September 2019 gate accepted: 23 December 2020

\begin{abstract}
Triassic successions of the present-day Arctic contain abundant and diverse assemblages of nonmarine palynomorphs that have provided important biostratigraphic information. Dinoflagellate cyst are biostratigraphically useful in marine intervals in the Upper Triassic. Based on published records, we present a compilation of 78 last occurrences (LOs), first occurrences (FOs), and some abundance events that are anticipated to have correlation potential in the Arctic region. Palynological work has been carried out in many Arctic areas, with extensive palynological research published on the Triassic successions of the Norwegian Barents Sea and Svalbard. An updated, recent palynological zonation scheme exists for that region, integrating previous schemes and illustrating the chronostratigraphic value of palynology in the Triassic. For the Lower and Middle Triassic, good ammonoid control ties the palynological zones to the chronostratigraphic scale. Independent control is sparse, and resolution is lower in the Upper Triassic, so that palynology is commonly the only biostratigraphic discipline available for chronostratigraphic dating and correlation.
\end{abstract}

\section{RÉSUMÉ}

Les successions triassiques de l'Arctique actuel abritent des assemblages abondants et diversifiés de palynomorphes terrestres qui ont livré des renseignements biostratigraphiques précieux. Les kystes dinoflagellés sont utiles sur le plan biostratigraphique dans les intervalles marins du Trias supérieur. Nous présentons, à partir de documents déjà publiés, une compilation de 78 dernières récurrences (DO) et premières récurrences (PO) ainsi que de certains phénomènes d'abondance entre lesquels nous anticipons des possibilités de corrélation dans la région arctique. Des travaux palynologiques ont été réalisés dans de nombreux secteurs de l'Arctique et des recherches palynologiques poussées ont été publiées sur la succession triassique de la zone norvégienne de la mer de Barents et Svalbard. Il existe pour cette région un schèma de zonation palynologique récent, mis à jour, qui intègre des schèmas antérieurs et illustre la valeur chronostratigraphique de la palynologie au cours du Trias. Dans le cas du Trias inférieur et moyen, une présence révélatrice d'ammonites relie les zones palynologiques à l'échelle chronostratigraphique. Le contrôle indépendant possible est clairsemé et la résolution est inférieure dans le cas du Trias supérieur, de sorte que la palynologie constitue communément la seule discipline biostratigraphique dont on dispose pour la datation et la corrélation chronostratigraphique.

[Traduit par la redaction]

\section{INTRODUCTION}

This article is a contribution to the Circum-Arctic Palynological Events (CAPE) project, providing a scheme of selected events for the Triassic Period. The Triassic extended from 251.90 to $201.36 \mathrm{Ma}$ according to Gradstein et al. (2020). The Triassic Period is divided into three epochs, Early Triassic, Middle Triassic (with a base at $246.70 \mathrm{Ma}$ ) and Late Triassic (with a base at $237.00 \mathrm{Ma}$ ). As palynomorphs are the most common and often the only fossil group preserved from this period, palynology is crucial for dating and refining biostratigraphical correlations of Triassic rocks. Triassic palynomorphs are primarily miospores (pollen and spores), although acritarchs, algae and foraminiferal linings also occur throughout. The algae include dinoflagellate cysts, which first occur globally in the latest part of Middle Triassic and reach a Triassic maximum in the early Norian. Triassic forms largely become extinct by the end of the Triassic period, but a few taxa survived the end-Triassic extinction into the Jurassic (Mangerud et al. 2018). Dinoflagellates cysts thus have biostratigraphical value in the Upper Triassic.

The present Triassic compilation will complement those for other periods in the CAPE series of papers in Atlantic 
Geology. When all papers in the series are complete, these will be provided as a "CAPE datapack" in Time Scale Creator (TSC; https://timescalecreator.org/index/index.php) and thus can be used with other data in TSC to make plots like that shown in Fig. 1. Figure 1 includes the age calibration in millions of years (Ma) using the 2020 version of TSC and in Gradstein et al. (2020).

The events compiled herein include last occurrences (LOs), first occurrences (FOs), and some abundance events. Their relationship to other fossil zonal schemes is shown in Fig. 1. Where possible, each event is correlated with the base of a chronostratigraphical unit, for example an ammonoid zone or a formal stage. If the event is not equivalent to the base of such a unit, then an estimation is given as a percentage above the base of the chronostratigraphical unit relative to the entire unit. Details of how a biostratigraphic datapack is constructed in TSC from such information are given in Bringué et al. (in press).

\section{PALYNOSTRATIGRAPHY}

Our approach in selecting events has been to use those with multiple reports from several locations, especially those that have a consistent stratigraphical position relative to other events, so that we can achieve a robust scheme. In order to provide independent age control, we emphasize events that are correlated with independently dated sections and especially those that have been dated using the standard ammonoid zonations. In addition, two rhenium-osmium (Re-Os) geochronological dates around the Anisian/ Ladinian boundary ( $\mathrm{Xu}$ et al. 2009) and the Ladinian/ Carnian boundary (Xu et al. 2014) are available from the Norwegian Arctic, providing two important independent ties to the absolute timescale.

A distinct Arctic event biostratigraphy is important because many taxa have different ranges from those in central Europe, and the quantitative composition of Arctic assemblages varies greatly from that region (Vigran et al. 2014; Paterson and Mangerud 2015). For the Late Triassic, the longest epoch in the period, challenges remain, as localities with independent age control from age-diagnostic macrofossils are rare, but a few important successions with, for example ammonoid control, have been documented (e.g., Paterson and Mangerud 2015).

In the Sverdrup Basin (Canadian Arctic Islands), previous published palynostratigraphic work is restricted to Fisher (1979) for the entire period, plus several publications for the earliest Triassic (Utting 1985, 1989, 1994) and the Late Triassic (including Felix 1975; Fisher and Bujak 1975; Bujak and Fisher 1976; Felix and Burbridge 1978; Suneby and Hills 1988). Additional data for the Sverdrup Basin is provided in Appendix C herein for dinocyst taxa in Romulus C-67 well.

Fisher (1979) provided a full Triassic zonation based on outcrops and wells in the Sverdrup Basin. He designated palynofloral zones I to IX, and discussed uncertainties related to calibration, independent dating and potential caving in cuttings samples in wells. He also described the assemblages characterizing his nine zones and provided a simplified range chart.

Utting $(1989,1994)$ provided short descriptions of lowermost Triassic assemblages from several sections in the basal parts of the Bjorne and Blind Fiord formations. He also studied the Bjorne Formation in five wells on Melville Island (Utting, 1989), and about 20 outcrop samples from the Blind Fiord Formation on Ellesmere Island (Utting $1989,1994)$. He did not provide any quantitative data and stated that "the assemblages were not subject to the same investigations as the Permian ones" (Utting 1994, p. 21) and established only the Tympanicysta stoschiana - Striatoabieites richteri Assemblage Zone.

Fisher and Bujak (1975) recorded Late Triassic assemblages from the Sverdrup Basin, including mostly informally named dinoflagellate cysts. The taxa were described in detail by Bujak and Fisher (1976) and their biostratigraphic utility has been confirmed by Bujak (Appendix C herein).

Suneby and Hills (1988) provided a palynological zonation of the Upper Triassic to Lower Jurassic successions of the Sverdrup Basin, involving the Barrow and Heiberg formations. They reported rich palynomorph assemblages of mostly miospores, but including dinoflagellate cysts, from four outcrop sections on Ellesmere Island (Fig. 2). They established four palynomorph zones, of which three are in the Upper Triassic section and the other in the Lower Jurassic section. Their oldest biozone (Triancoraesporites ancorae - Camarozonosporites laevigatus Biozone) was divided into two subzones, the Kyrtomosporis speciosus - Aratrisporites coryliseminis Subzone and the Noricysta pannucea Heibergella asymmetrica Subzone. The oldest subzone was assigned an ?early Norian to late middle Norian age based on palynological correlation; the youngest subzone was assigned a late Norian - ?early Rhaetian age based on bivalves and a single ammonoid (Norford et al. 1973; Embry 1982). The two youngest Triassic biozones are the Limbosporites lundbladiae - Ricciisporites tuberculatus Biozone and the Retitriletes austroclavatidites - Chasmatosporites magnolioides Biozone, which they assigned to the latest Norian to Rhaetian, and latest Rhaetian to early Hettangian (Early Jurassic) respectively. However, Lindström (2016) considered both zones to be Rhaetian and suggested that they represent a preend Triassic extinction and extinction palynofloras respectively.

In offshore northern Alaska and the Chukchi Sea, palynostratigraphical work is restricted to exploration wells that mostly have unpublished and confidential data. Exceptions are Fireweed 1 (offshore northern Alaska) and Klondike OCS-Y-1482 (Chukchi Sea) for which Triassic species abundances and events are documented in Appendix $\mathrm{C}$ herein.

From the Barents Sea area, Hochuli et al. (1989) published

Figure 1. (next page) Chronostratigraphic plot of stratigraphically significant Triassic palynological events. Modified from a Time Scale Creator plot and using the GTS 2020 time scale (Gradstein et al. 2020). 


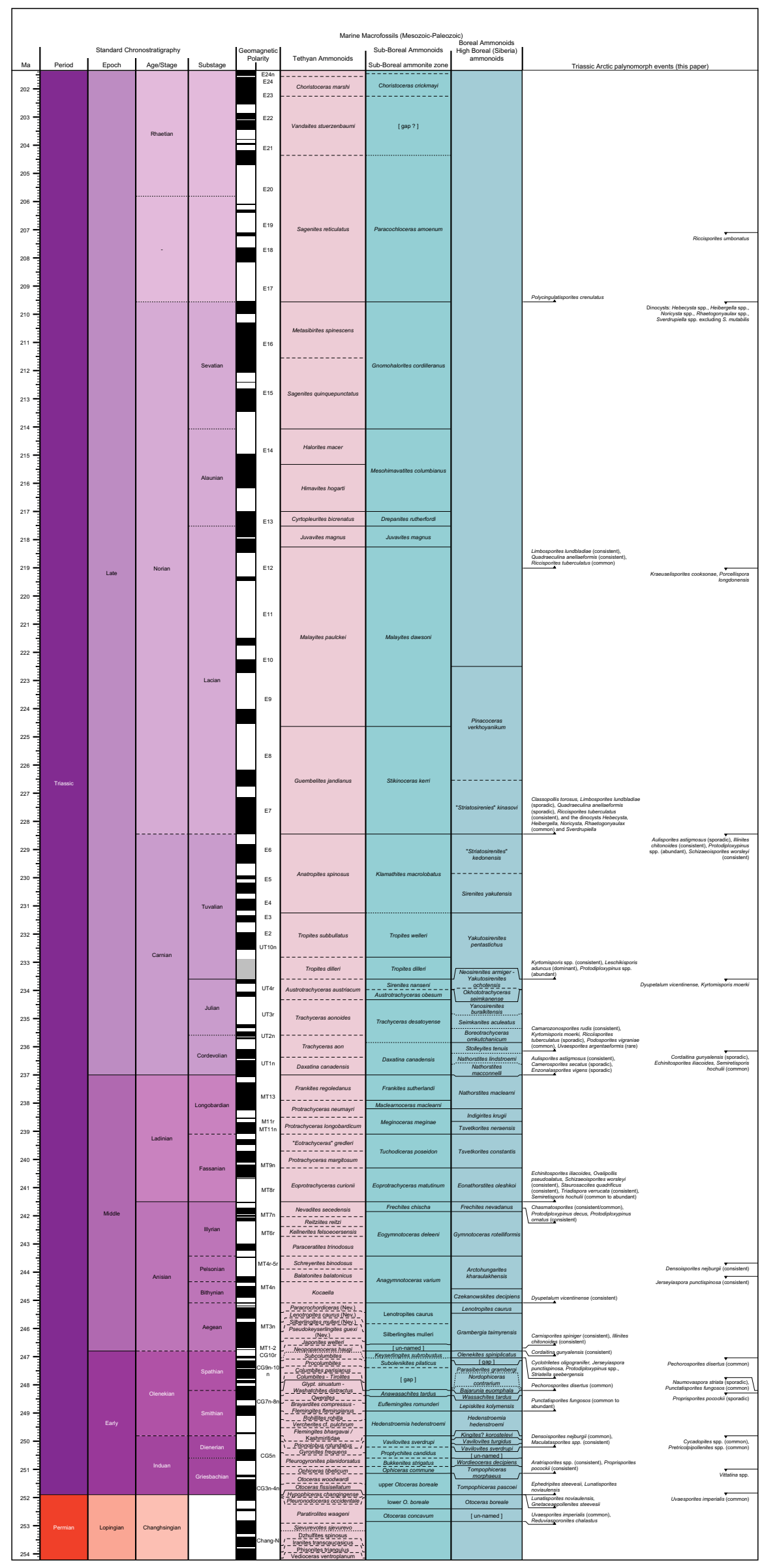




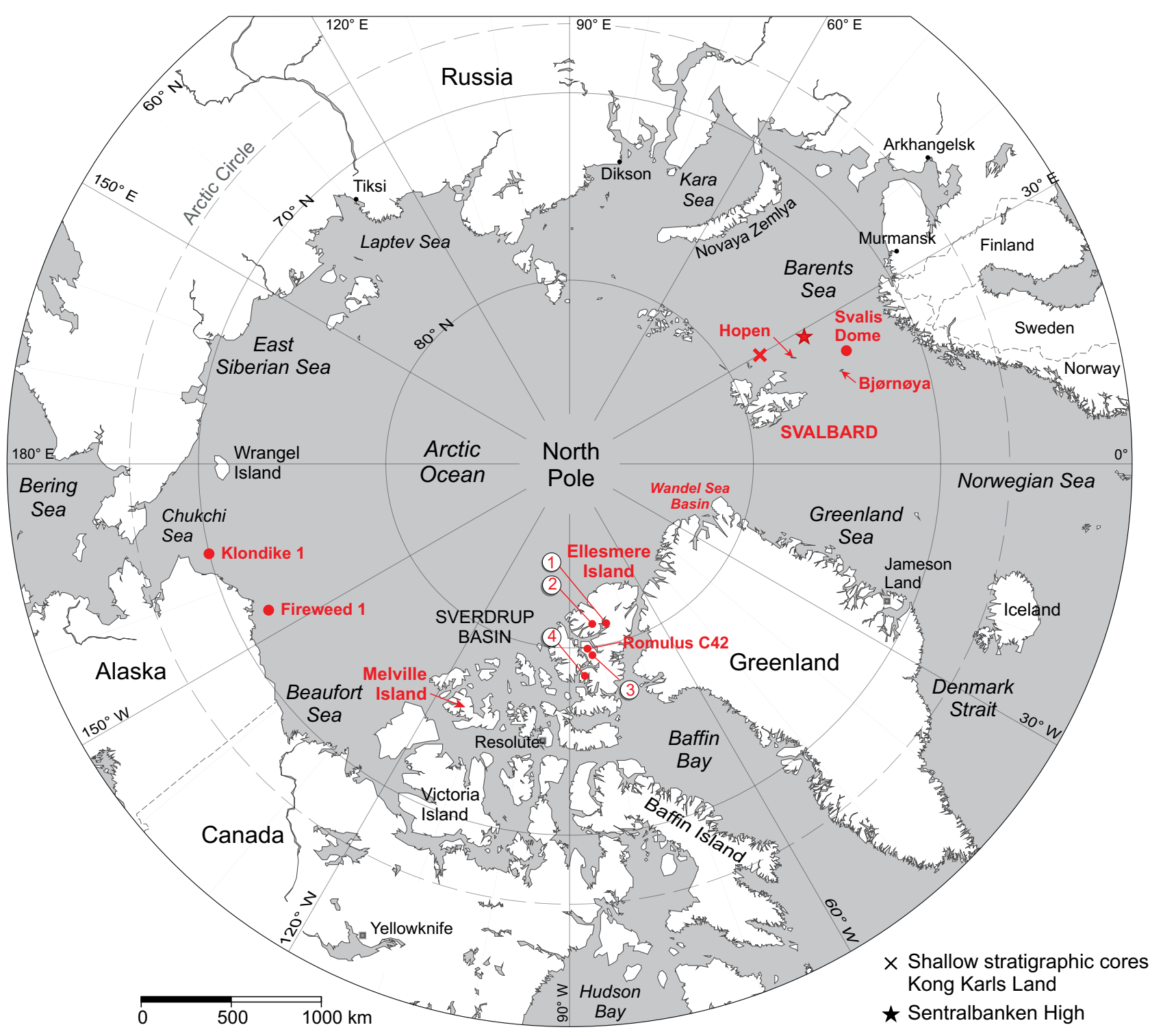

Figure 2. Circumpolar projection map showing the main Triassic localities discussed. Numbers 1 to 4 on Ellesmere Island refer to localities in Suneby and Hills (1988): McKinley Bay, Blackwalder Anticline, Fosheim Ancticline and Raanes Peninsula respectively.

an informal palynozonation comprising 16 zones, encompassing the entire Triassic based on last occurrence and relative abundance data, but they provided little documentation. Based on shallow-core material from the Svalis Dome in the central Barents Sea, Vigran et al. (1998) defined eight Lower to Middle Triassic (Induan to Ladinian) concurrent range zones, six of which had ammonoid control. These shallow stratigraphical cores, each a maximum of $580 \mathrm{~m}$ long and drilled with piggyback coring technique using a diamond bit (Rise and Sættem 1994), provide a unique database for the Norwegian Barents Sea area. All coring sites are associated with high resolution seismic, enabling correlation to conventional seismics.

Vigran et al. (2014) published the most comprehensive Triassic zonation to date from the Arctic, encompassing the Sassendalen Group and the Triassic parts of the overlying
Kapp Toscana Group for Svalbard and the Barents Sea. This study involved samples from outcrops, shallow cores and exploration wells, and extended from about $70-78^{\circ} \mathrm{N}$. They defined 15 formal composite assemblage zones (CAZ), including seven spanning the uppermost Permian (Changhsingian) to Olenekian, four in the Middle Triassic, and four covering the Upper Triassic (Fig. 3). They described each zone, integrated previous zonations, assigned ages and reference sections, and discussed earlier palynological work from the Norwegian Arctic. They also provided range charts and descriptions of the palynological assemblages for each locality. The authors acknowledged, however, that a weakness was that their study was based on separate investigations done over several years, each with a different aim and approach.

More recently, several studies have been published on the 
Middle to Upper Triassic palynostratigraphy of the Norwegian Arctic, focusing especially on a refinement of the palynostratigraphy of the Upper Triassic (Paterson and Mangerud 2015, 2017, 2019; Paterson et al. 2016, 2017, 2018), including quantitative data for all localities. Paterson et al. (2018) tied their Assemblage SBH-II from the lower to middle de Geerdalen Formation on Sentralbanken (Fig. 2) to the Ladinian/Carnian boundary based on Re-Os radiometric dating from offshore Kong Karls Land cores 7831/2-U-1 and 2-U-2 (Xu et al. 2014). This synthesis culminated in Paterson and Mangerud (2019), which integrated the zonation of Vigran et al. (2014), adding resolution to the Upper Triassic palynostratigraphy of the Norwegian Arctic. The palynomorph ranges included herein are mainly based on palynological work from the Barents Sea area. Of special importance are the palynological zones that are tied to ammonoid zones (Hochuli et al. 1989; Mørk et al. 1990, 1999; Mangerud and Rømuld 1991; Vigran et al. 1998, 2014; Paterson and Mangerud 2015, 2019).

So far, no palynological work exists from the Triassic of the Wandel Sea Basin in northeastern Greenland, except for a recent paper by Lindström et al. (2020). Farther south, in East Greenland, a few palynological studies of Rhaetian stra-ta have been published (Pedersen and Lund 1980; Mander 2011, Mander et al. 2010, 2013); however, these show closer afffnities to palynofloras from northwestern Europe. In contrast, although data is relatively sparse, older Triassic floras from East Greenland closely resemble coeval assemblages from the Barents Sea area (Balme 1980; Piasecki 1984; Schneebeli-Hermann et al. 2017). This resemblance is also seen in the palynological records from mid-Norway, which occupied approximately the same latitude as East Greenland during the Triassic (e.g., Bugge et al. 2002b; Hochuli et al. 2009).

Substantial palynological work has been done on Triassic successions in Russia, but most have focused on systematics, and most are in Russian (sometimes with short English abstracts). The different taxonomic approach and general lack of illustrations used for Russian miospores makes compari-son with other data difficult and will require future collaboration between Russian and non-Russian workers. The only comparisons so far were by Mørk et al. (1993), who attempted to compare palynological assemblages of the Russian and Norwegian sectors of the Barents Sea, and by Gilmullina et al. (2020). The latter authors indicated that several of the Norwegian zones described by Vigran et al. (2014) and Paterson and Mangerud (2019) are recognizable in the Russian sector. Among Russian publications, Yaroshenko et al. (1991) reported on Lower Triassic palynology of the Pechora area. Works on the Upper Triassic include those of Fefilova (1986, 1988, 1990) and of Ilyina and Egorov (2008), who published on palynology from the Carnian of Siberia.

\section{PALYNOEVENTS}

A summary of the following events in spreadsheet format is provided as Appendix B. All taxon names with authorship are listed in Appendix A.

\section{FO of common Uvaesporites imperialis}

The FO for common Uvaesporites imperialis is based on occurrences from multiple localities. In the Sverdrup Basin it is recorded from near the base of the Blind Fiord Formation (Fisher 1979, Utting 1994), where records exist of the ammonoid Otoceras concavum, a taxon previously regarded as representing the base of the Triassic. However, with the recent designation of a GSSP at the base of the Triassic, the Otoceras concavum Zone is now within the uppermost Permian. In Svalbard, Uvaesporites imperialis has been recorded at various locations, including the Deltadalen and Festningen sections, where the ammonoid Otoceras boreale was also recorded (Mørk et al. 1999; Vigran et al. 2014). In both the Norwegian and Canadian Arctic, and in North East Greenland, Uvaesporites imperialis commonly occurs in tetrads. Abundant Uvaesporites imperialis is also recorded on the Finnmark Platform, Barents Sea, where two shallow stratigraphic cores provide detailed palynology (Mangerud 1994; Hochuli et al. 2010) across the Permian/Triassic boundary. Palynology that was linked to high-resolution carbon isotope curves across the boundary layers (Looy et al. 2001; Twitchett et al. 2001; Hermann et al. 2010; Hochuli et al. 2010) provides important understanding of the boundary interval and correlation to the global stratotype. Vigran et al. (2014) linked the base of abundant Uvaesporites imperialis to the very latest Permian (Changhsingian), although for practical purposes, this event is often related to the base of the Triassic.

The FO of common Uvaesporites imperialis is taken as the base of the ammonoid Otoceras concavum zone.

\section{FO of Reduviasporonites chalastus}

The FO of Reduviasporonites chalastus is based on multiple records from the Arctic, including the Sverdrup Basin, where Utting (1994) defined his oldest Triassic palynology zone based on this species (Utting used the name Tympanicysta stoschiana, now considered a taxonomic junior synonym of Reduviasporonites chalastus). Utting $(1985,1989)$ recorded the species from the Blind Fiord Formation. It has also been recorded from the Norwegian Arctic, including the Finnmark Platform, Barents Sea (Mangerud 1994; Hochuli et al. 2010) and Svalbard (Mørk et al. 1999; Vigran et al. 2014). Reduviasporonites chalastus is of probable algal origin (Foster et al. 2002; Hochuli 2016). For discussion of age, see also Uvaesporites imperialis.

The FO of Reduviasporonites chalastus is taken as the base of the ammonoid Otoceras concavum zone.

\section{FO of Lunatisporites noviaulensis}

The FO of Lunatisporites noviaulensis is based on multiple records from the Arctic, including from the Blind Fiord and 

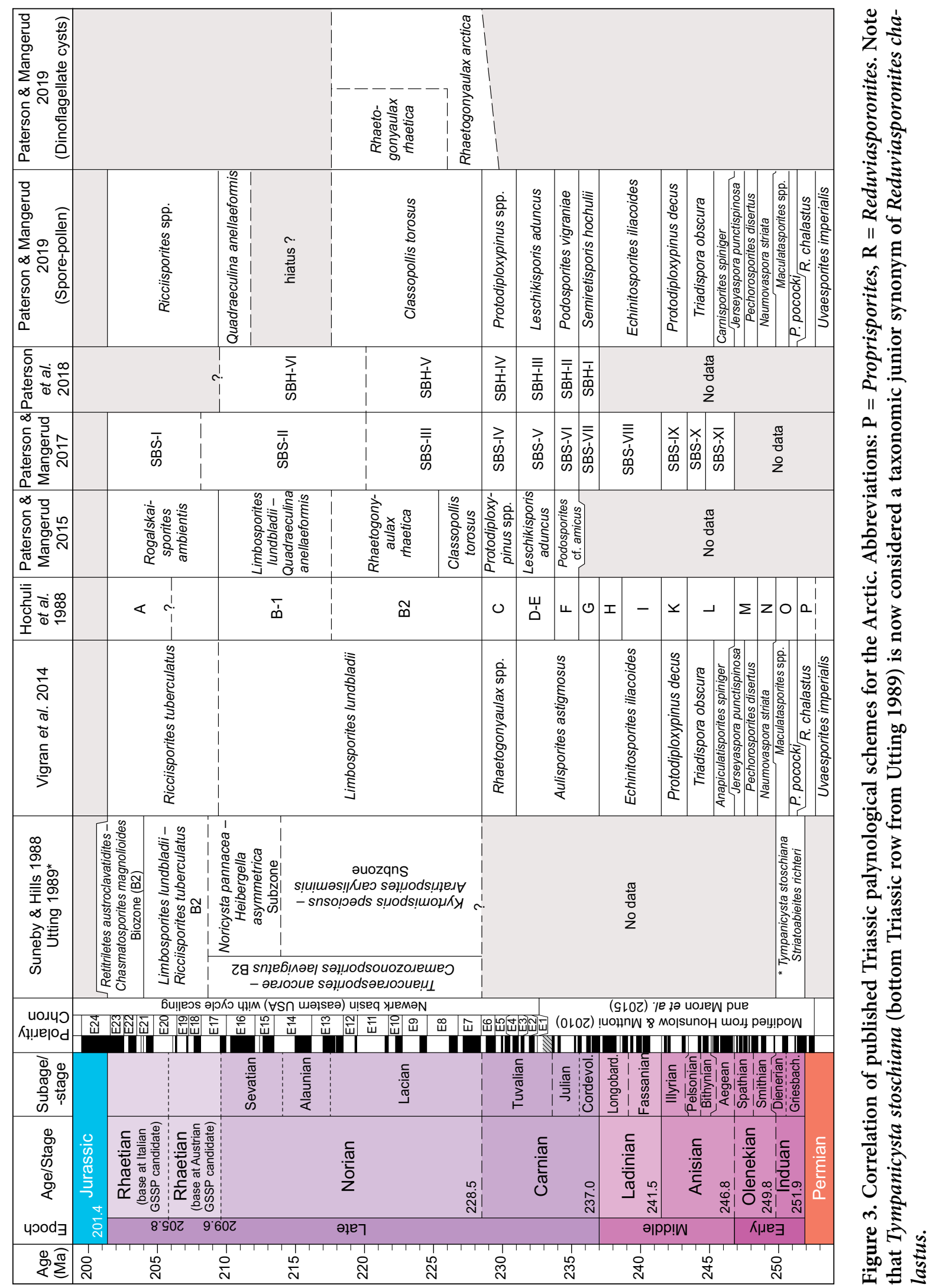

Bjorne formations in the Sverdrup Basin (Utting 1985, 1989, 1994). Lunatisporites noviaulensis has also been recorded from basal Triassic on the Finnmark Platform (Mangerud 1994), with the FO slightly above the base of the Uvaesporites imperialis acme.

The FO of Lunatisporites noviaulensis is taken as the base of the Griesbachian (equivalent to the Induan). 


\section{FO of Ephedripites steevesii}

The FO of Ephedripites steevesii is based on multiple records from the Arctic, including the Sverdrup Basin (Utting 1985, 1989, 1994, from the Blind Fiord Formation) and Spitsbergen (Vigran et al. 2014). On the Finnmark Platform of the Barents Sea, one of us (NWP) has observed that this species appears abruptly in a short interval corresponding to the Permian/Triassic boundary carbon isotope excursion.

The FO of Ephedripites steevesii is here taken as the base of the Griesbachian (equivalent to the Induan).

\section{LO of common Uvaesporites imperialis}

In the Sverdrup Basin, Uvaesporites imperialis occurs in the Bjorne and Blind Fiord Formation, where the ammonoid Otoceras boreale is also recorded (Tozer 1967). In the Barents Sea, the LO of common Uvaesporites imperialis occurs close to the base of the Triassic according to Hermann et al. (2010). Mangerud (1994) also noted this event. The event is linked to high-resolution carbon-isotope curves across the boundary layers (Hermann et al. 2010; Hochuli et al. 2010), providing correlation to the global stratotype and indicating a LO of common Uvaesporites imperialis at about 20-30 ka above its FO, which is at the base of the ammonoid Otoceras concavum Zone. In Svalbard the event is recorded at various locations, including the Deltadalen section, where the ammonoid Otoceras boreale was also recorded (Mørk et al. 1999; Vigran et al. 2014). In both the Norwegian and Canadian Arctic, Uvaesporites imperialis commonly occurs in tetrads (e.g., Mangerud 1994; Hochuli et al. 2017; GM, personal observations).

The LO of common Uvaesporites imperialis is here taken as $5 \%$ above the base of the Griesbachian (equivalent to the base of the Induan).

\section{FO of consistent Proprisporites pocockii}

The FO of consistent Proprisporites pocockii is based on multiple records from the Arctic, including those from the Sverdrup Basin (Utting 1985, from the Bjorne Formation). It has been also recorded from the Finnmark Platform of the Barents Sea (Mangerud 1994), and from the Vardebuka Formation on Svalbard (Mangerud and Konieczny 1993; Mørk et al. 1999). Based on multiple datasets, Vigran et al. (2014) used this species to define their Proprisporites pocockii Composite Assemblage Zone. This zone correlates to similar assemblages in the Svalis Dome (Vigran et al. 1998), where records occur of the ammonoid Ophiceras, which is assigned to the ammonoid Ophiceras commune Zone of late Griesbachian age.

The FO of consistent Proprisporites pocockii is here taken as the base of the ammonoid Ophiceras commune zone.

\section{FO of consistent Aratrisporites}

The FO of consistent Aratrisporites is based on multiple records from the Norwegian Arctic. Based on several data- sets, Vigran et al. (2014) placed the FO of this event at the base of their Proprisporites pocockii Composite Assemblage Zone, which correlates to similar assemblages in the Svalis Dome (Vigran et al. 1998). At the latter locality, records occur of the ammonoid Ophiceras, which is assigned to the ammonoid Ophiceras commune Zone of late Griesbachian age. In East Greenland SchneebeliHermann et al. (2017) recorded Aratrisporites in the Griesbachian succession.

The FO of consistent Aratrisporites is is here taken as the base of the ammonoid Ophiceras commune Zone.

\section{LO of Vittatina}

The LO of Vittatina occurs near the top of the Griesbachian Substage. Vittatina is regarded as a typical Permian taxon, fading out gradually above the Permian/ Triassic boundary, although there has been debate as to whether Triassic records represent reworking (e.g., Hochuli et al. 1989; Mangerud 1994; Utting et al. 2004; Vigran et al. 2014). Vigran et al. (2014) concluded that Vittatina ranges sporadically up to the top of their Proprisporites pocockii Composite Assemblage Zone. The assemblage characterizing this zone correlates with similar assemblages in the Svalis Dome (Vigran et al. 1998), where records occur of the ammonoid Ophiceras, which is assigned to the ammonoid Ophiceras commune Zone of late Griesbachian age. The LO of Vittatina is also recorded further south: in East Greenland, Schneebeli-Hermann et al. (2017) recorded Vittatina ranging into the Dienerian.

The LO of Vittatina is taken as 70\% up from the base of the Griesbachian (equivalent to the base of the Induan).

\section{FO of common Densoisporites nejburgii}

The FO of common Densoisporites nejburgii is based on multiple records from the Arctic, including those from the Sverdrup Basin (Fisher 1979) and from the Norwegian Arctic (Vigran et al. 2014).

The FO of common Densoisporites nejburgii is taken here as the base of the Boreal ammonoid Vavilovites sverdrupi Zone.

\section{FO of consistent Maculatasporites}

The FO of consistent Maculatasporites is based on multiple records from the Norwegian Arctic. It defines the base of the Maculatasporites Composite Assemblage Zone of Vigran et al. (2014), who correlated assemblages from the Svalis Dome containing Maculatasporites spp. to similar assemblages from Bjørnøya (Mørk et al. 1990); at the latter locality, Dienerian ammonoids of the ammonoid Vavilovites sverdrupi Zone were recorded from the Urd Formation. The early Induan is dominated by taeniate bisaccates, but there seems generally to be a major turnover in the Dienerian, continuing in the Smithian.

The FO of consistent Maculatasporites is taken here as the base of the Boreal ammonoid Vavilovites sverdrupi Zone. 


\section{LOs of common Cycadopites and Pretricolpipollenites}

The LO of common Cycadopites and Pretricolpipollenites is based on multiple records from the Norwegian Arctic. Their LOs corresponds with the top of the Maculatasporites Composite Assemblage Zone of Vigran et al. (2014), who correlated assemblages with these taxa to similar assemblages from Bjørnøya (Mørk et al. 1990), where ammonoids of the Vavilovites sverdrupi Zone of Dienerian age were recorded from the Urd Formation. Hochuli et al. (1989) also mentions a distinctive palynoflora with common Cycadopites and Pretricolpipollenites from a sample dated Dienerian by ammonoids in the Bertilryggen section on Spitsbergen.

The LOs of common Cycadopites and Pretricolpipollenites are taken as the base of the Smithian (lower Olenekian).

\section{FO of common-abundant Punctatisporites fungosus}

The FO of common to abundant Punctatisporites fungosus is based on multiple records from the Norwegian Arctic. It has been recorded by Vigran et al. (2014) and Rossi et al. (2019) from the base of the Naumovaspora striata Composite Assemblage Zone from several surface sections and wells. The zone is dated by its co-occurrence with the ammonoid Wasachites tardus from the Svalis Dome (Vigran et al. 1998, 2014); however, a gap occurs in the coring between this core and the underlying core, so the FO could be somewhat older. Common Punctatisporites fungosus has also been recorded in assemblages from beds with the early Olenekian (Smithian) ammonoid Eufleminigites romunderi at Vikinghøgda (Mørk et al. 1999), from Peary Land, North-East Greenland (Lindström et al. 2020) and at Bjørnøya (Mørk et al. 1990); at that locality, ammonoids were recorded from the middle parts of the Urd Formation. Similarly, in the Russian Barents Sea, the FO of Punctatisporites fungosus is recorded in the Smithian $\mathrm{T}_{1} \mathrm{O}_{1}$ palynocomplex (Mørk et al. 1993; Fefilova 2013a).

The FO base of common to abundant Punctatisporites fungosus is taken here as the base of the Boreal ammonoid Euflemingites romunderi Zone.

\section{LO of sporadic Proprisporites pocockii}

The LO of sporadic Proprisporites pocockii is based on data from Vigran et al. (1998, 2014), who recorded infrequent occurrences of this species ranging up to the middle of their Naumovaspora striata Composite Assemblage Zone. The assemblage comprising the latter zone was recorded in beds where the ammonoid Wasatchites tardus Zone was defined in the Svalis Dome. On Bjørnøya, Proprisporites pocockii occurs sporadically in the Urd Formation (Mørk et al. 1990).

The LO of sporadic Proprisporites pocockii is taken as 50\% up from the base of the ammonoid Wasatchites tardus Zone.

\section{LO of sporadic Naumovaspora striata}

The LO of sporadic Naumovaspora striata is based on multiple records from the Norwegian Arctic. The LO of Naumovaspora striata defines the top of the Naumovaspora striata Assemblage Zone (Vigran et al. 2014), which has been recorded in multiple localities. In the reference section for this zone (a core at the Svalis Dome in the Barents Sea), the latest Olenekian (late Smithian) ammonoid index taxon Wasachites tardus was recorded. A similar assemblage was also documented on Bjørnøya, from beds with the slightly older ammonoid Euflemingites romunderi (Mørk et al.1990).

The LO of sporadic Naumovaspora striata is taken here as the base of the Spathian (upper Olenekian).

\section{LO of common Punctatisporites fungosus}

The LO of common to abundant Punctatisporites fungosus is based on multiple records from the Norwegian Arctic. It partly defines the base of the Naumovaspora striata Assemblage Zone of Vigran et al. (2014), which was recorded from a core from Svalis Dome. Vigran et al. dated this zone as Smithian based on records of the ammonoid Wasachites tardus. In wells from the Barents Sea, this event corresponds to the transition between the Havert and Klappmyss formations (Rossi et al. 2019). A similar assemblage was recorded at Bjørnøya, from beds containing the ammonoid Euflemingites romunderi (Mørk et al. 1990).

The LO of common Punctatisporites fungosus is taken here as the base of the Spathian (upper Olenekian).

\section{FO of common Pechorosporites disertus}

The FO of common Pechorosporites disertus is based on multiple records from the Norwegian Arctic. Its FO defines the base of the Pechorosporites disertus Assemblage Zone according to Vigran et al. (2014), dated as early Spathian. However, little faunal evidence exists for the age of this zone, as it occurs between ammonoid-dated Smithian and late Spathian sections in the Svalis Dome.

The FO of common Pechorosporites disertus is taken here as the base of the Spathian (upper Olenekian).

\section{LO of common Pechorosporites disertus}

The LO of common Pechorosporites disertus is based on multiple records from the Norwegian Arctic. Its LO defines the top of the Pechorosporites disertus Assemblage Zone (Vigran et al. 1998, 2014) and has been recorded in the upper-most Klappmyss Formation, where it has been assigned an early Spathian age. However, little faunal evidence exists for the age of this zone, as it occurs between ammonoid-dated Smithian and late Spathian sections. The appearance of the taxon in the Russian Barents Sea seem to be slightly earlier, with occurrences reported in the Dienerian T1i2 palyno-complex (Fefilova 2013a, b). 
The LO of common Pechorosporites disertus is taken here as the base of the ammonoid Keyserlingites subrobustus Zone.

\section{FO of Jerseyiaspora punctispinosa}

The FO of Jerseyiaspora punctispinosa is based on multiple records from the Norwegian Arctic. It was reported by Mangerud and Rømuld (1991) from the Svalis Dome, in beds with the ammonoid Keyserlingites subrobustus. It has also been recorded in various localities in Svalbard, including the type section of the Vikinghøgda Formation (from the upper part of the Vendomdalen Member; Mørk et al. 1999), and from several exploration wells (Vigran et al. 2014; Paterson and Mangerud 2017; Rossi et al. 2019). The FO of Jerseyiaspora punctispinosa defines the base of the Jerseyiaspora punctispinosa Composite Assemblage Zone (Vigran et al. 2014).

The FO of Jerseyiaspora punctispinosa is taken here as the base of the late Spathian Boreal ammonoid Keyserlingites subrobustus Zone.

\section{FO of Protodiploxypinus}

The FO of Protodiploxypinus is based on multiple records from the Norwegian Arctic. Mangerud and Rømuld (1991) reported its FO from the Svalis Dome, in beds containing the ammonoid Keyserlingites subrobustus. The FO of Protodiploxypinus also partly defines the base of the Jerseyiaspora punctispinosa Composite Assemblage Zone (Vigran et al. 2014).

The FO of Protodiploxypinus is taken here as the base of the Boreal ammonoid Keyserlingites subrobustus Zone.

\section{FO of Cyclotriletes oligogranifer}

The FO of Cyclotriletes oligogranifer is based on multiple records from the Norwegian Arctic. It was reported by Mangerud and Rømuld (1991) from the Svalis Dome, with its LO in beds with the late Spathian ammonoid Keyserlingites subrobustus. It has also been recorded in various localities in Svalbard (Vigran et al. 2014), appearing approximately at the same time as other species of Cyclotriletes such as Cyclotriletes pustulatus.

The FO of Cyclotriletes oligogranifer is taken here as the base of the Boreal ammonoid Keyserlingites subrobustus Zone.

\section{FO of sporadic Striatella seebergensis}

The FO of sporadic Striatella seebergensis is based on multiple records from the Arctic, including the Sverdrup Basin (Fisher 1979). In the Norwegian Arctic it was reported by Mangerud and Rømuld (1991) from the Svalis Dome, in beds with the late Spathian ammonoid Keyserlingites subrobustus. It has also been recorded from various localities in Svalbard, including the type-section of the Vikinghøgda
Formation (from the upper part of the Vendomdalen Member; Mørk et al. 1999), and from several exploration wells (Vigran et al. 2014; Rossi et al. 2019). Its FO partly defines the base of the Jerseyiaspora punctispinosa Composite Assemblage Zone (Vigran et al. 2014).

The FO of sporadic Striatella seebergensis is taken here as the base of the Boreal ammonoid Keyserlingites subrobustus Zone.

\section{FO of consistent Carnisporites spiniger}

The FO of consistent Carnisporites spiniger is based on multiple records from the Norwegian Arctic. Mangerud and Rømuld (1991) and Vigran et al. (1998) recorded its consistent FO from the Steinkobbe Formation at the Svalis Dome, from a core with the ammonoid Karangatites evolutus, which is dated as early Anisian. Vigran et al. (2014) defined the Carnisporites spiniger Composite Assemblage Zone (called Anapiculatisporites spiniger Assemblage Zone therein) based on the FO of consistent Carnisporites spiniger. Its FO has been also recorded from a shallow core in the Sentralbanken area, together with ammonoids of the Lenotropis caurus Zone (Vigran et al. 2014), demonstrating that it ranges up into the Anisian. The LO Carnisporites spiniger was also noted by Paterson and Mangerud (2017) in the lower Kobbe Formation from the Nordkapp Basin, southern Barents Sea.

The FO of consistent Carnisporites spiniger is taken here as the base of the Boreal ammonoid Karangatites evolutus Zone.

\section{FO of consistent Illinites chitonoides}

The FO of consistent Illinites chitonoides is based on multiple records from the Norwegian Arctic. Mangerud and Rømuld (1991) and Vigran et al. (1998) recorded its FO from the Svalis Dome, from a core with the ammonoid Karangatites evolutus, which is regarded as early Anisian. Vigran et al. (2014) also noted that its consistent FO corresponds with the base of their Carnisporites spiniger Composite Assemblage Zone (called Anapiculatisporites spiniger Assemblage Zone therein).

The FO of consistent Illinites chitonoides is taken here as the base of the Boreal ammonoid Karangatites evolutus Zone.

\section{FO of consistent Cordaitina gunyalensis}

Mangerud and Rømuld (1991) and Vigran et al. (1998) recorded the FO of consistent (and in some intervals common) Cordaitina gunyalensis from the middle part of the middle Anisian ammonoid Anagymnotoceras varium Zone in the Svalis Dome. However, Vigran et al. (2014) reported a considerably older FO for the taxon, at the base of their early Spathian Pechosporites disertus Composite Assemblage Zone (Vigran et al. 2014, fig 3b), indicating some uncertainty as to its FO. This distinct monosaccate pollen is a good index species; but because of its large size (often around 
$200 \mu \mathrm{m})$ it may not always survive routine palynological laboratory procedures intact and is often recorded as specimens with a missing corpus.

The FO of consistent Cordaitina gunyalensis is taken here as the base of the Anisian.

\section{FO of consistent Dyupetalum vicentinense}

The FO of consistent Dyupetalum vicentinense is based on multiple records from the Norwegian Arctic. Although rare, the species has been recorded from many localities and is a characteristic element of the Triadispora obscura Composite Assemblage Zone (Vigran et al. 2014). This zone has been found in in association with the ammonoid Anagymnotoceras varium in the Svalis Dome, Barents Sea (Mangerud and Rømuld 1991). Hochuli et al. (1989) recorded this species with a lowest occurrence at or near the base of their Assemblage $\mathrm{K}$, dated as late Anisian; however, it was later recorded in older sections dated by ammonoids. A single occurrence of Dyupetalum vicentinense was also noted in the Klappmyss Formation, from shallow-core material from the Barents Sea, in association with the late Spathian Jerseyiaspora punctispinosa Composite Assemblage Zone (Vigran et al. 2014, p. 145).

The FO of consistent Dyupetalum vicentinense is taken here as the base of the middle Anisian Boreal ammonoid Anagymnotoceras varium Zone.

\section{LO of consistent Densoisporites nejburgii}

The LO of consistent Densoisporites nejburgii is based on multiple records from the Norwegian Arctic. Hochuli et al. (1989) noted that its first downhole occurrence was around the top of the middle Anisian (their Assemblage L). In the Barents Sea, Mangerud and Rømuld (1991) recorded its youngest occurrence in the middle of their Anagymnotoceras varium ammonoid Zone in the Svalis Dome. Vigran et al. (2014) noted its LO within their Carnisporites spiniger Composite Assemblage Zone (called Anapiculatisporites spiniger Assemblage Zone therein) of early Anisian age.

The LO of Densoisporites nejburgii is taken here as $50 \%$ up from the base of the ammonoid Anagymnotoceras varium Zone.

\section{LO of consistent Jerseyiaspora punctispinosa}

The LO of consistent Jerseyiaspora punctispinosa is based on multiple records from the Norwegian Arctic. In the Barents Sea, Mangerud and Rømuld (1991) and Vigran et al. (1998) recorded its consistent occurrence in the Svalis Dome from a core with the ammonoid Anagymnotoceras varium, corresponding to the top of the middle Anisian. Only one occurrence is recorded in a younger core at the same location, probably representing reworking. Vigran et al. (2014) also recorded it as common from exploration wells and defined its LO as the top of theirTriadispora obscura Com- posite Assemblage Zone, an observation supported also by records from Hochuli et al. (1989). From the southern Barents Sea, Paterson and Mangerud (2017) noted the LO of consistent Jerseyiaspora punctispinosa in the middle part of the Kobbe Formation. Somewhat younger occurrences of Jerseyiaspora punctispinosa in the Ladinian Echinitosporites iliacoides and Carnian Aulisporites astigmosus Composite Assemblage Zone were interpreted by Vigran et al. (2014, p. $130,149)$ as reworking.

The LO of consistent Jerseyiaspora punctispinosa is taken here as $50 \%$ up from the base of the Anisian.

\section{FO of consistent/common Chasmatosporites}

The FO of consistent to common Chasmatosporites is based on multiple records from the Norwegian Arctic. This taxon was recorded from the base of the Protodiploxypinus decus Composite Assemblage Zone of Vigran et al. (2014) with ammonoids of the Frechites laqueatus Zone, which is regarded as late Anisian (Vigran et al. 1998). Mueller et al. (2016) reported consistent Chasmatosporites from the base of the Tschermakfjellet Formation on Spitsbergen, which they assigned to the Julian (lower Carnian).

The FO of consistent to common Chasmatosporites is taken here as the base of the late Anisian ammonoid Frechites laqueatus Zone.

\section{FO Protodiploxypinus decus}

The FO of Protodiploxypinus decus is based on multiple records from the Norwegian Arctic. In the Barents Sea, it was recorded from the upper part of the Steinkobbe Formation in the Svalis Dome by Vigran et al. (1998). Its FO was used to define the Protodiploxypinus decus Composite Assemblage Zone of Vigran et al. (2014) and was calibrated to the upper Anisian ammonoid Frechites laqueatus in the same core. Note that Vigran et al. (2014, p. 71) erroneously stated that the LO (rather than FO) of Protodiploxypinus decus is in this ammonoid zone. Those authors also reported rare occurrences of Protodiploxypinus decus in the early Anisian Anapiculatisporites spiniger Composite Assemblage Zone, but these are likely misidentified.

The FO of Protodiploxypinus decus is taken here as the base of the ammonoid Frechites laqueatus Zone.

\section{FO of consistent Protodiploxypinus ornatus}

The FO of consistent Protodiploxypinus ornatus is based on multiple records from the Norwegian Arctic. Its FO corresponds to the base of Protodiploxypinus decus Composite Assemblage Zone of Vigran et al. (2014), which is calibrated to ammonoid records of the Frechites laqueatus Zone, of late Anisian age. Note that Vigran et al. 2014 (p. 71) erroneously stated that the LO (rather than the FO) of Protodiploxypinus ornatus is in this ammonoid zone.

The FO of consistent Protodiploxypinus ornatus is taken here as the base of the ammonoid Frechites laqueatus Zone. 


\section{FO of Echinitosporites iliacoides}

The FO of Echinitosporites iliacoides is based on multiple records from the Norwegian Arctic. Its base defines the base of the Echinitosporites iliacoides Composite Assemblage Zone of Vigran et al. (2014), which was established at the base of the Ladinian Stage. This event is constrained by late Anisian ammonoid dating just below. Echinitosporites iliacoides is not very common but is a very distinctive marker species. It is reported from several locations in the Barents Sea (Hochuli et al. 1989; Mørk et al. 1990; Bugge et al. 2002a; Vigran et al. 1998, 2014; Paterson and Mangerud 2017, 2019; Paterson et al. 2018) and from Svalbard (Mørk et al. 1990, 1999); despite its small size and relatively rare occurrence, it is an important marker.

The FO of Echinitosporites iliacoides is taken here as the base of the Ladinian.

\section{FO of consistent Schizaeoisporites worsleyi}

The FO of consistent Schizaeoisporites worsleyi is based on multiple records in the Norwegian Arctic. It was first described by Bjærke and Manum (1977) from Hopen Island. Vigran et al. (1998) recorded it in three Ladinian cores in the Svalis Dome, Barents Sea. No independent faunal evidence exists from the three Ladinian cores in the Svalis Dome, but the cored succession overlies upper Anisian successions dated by ammonoids. The range base of Schizaeoisporites worsleyi corresponds approximately to the base of the Echinitosporites iliacoides Composite Assemblage Zone of Vigran et al. (2014), which is set at the base of the Ladinian Stage. Similarly, in the Russian Barents Sea, Schizaeoisporites worsleyi has an FO in the Ladinian $\mathrm{T}_{2}$ Zone (Mørk et al. 1993). A single occurrence of this taxon has been reported from the middle Anisian Triadispora obscura Composite Assemblage Zone from central Spitsbergen (Vigran et al. 2014, p. 98). In the Barents Sea, a few records of Schizaeoisporites worsleyi extend down to the early Anisian Anapiculatisporites spiniger Composite Assemblage Zone (Vigran et al. 2014, p. 189).

The FO of consistent Schizaeoisporites worsleyi is here taken as the base of the Ladinian.

\section{FO of consistent Triadispora verrucata}

The FO of consistent Triadispora verrucata is based on multiple records from the Norwegian Arctic (e.g., Hochuli et al. 1989; Vigran et al. 1998; Paterson and Mangerud 2017). Its base corresponds approximately to the base of the Echinitosporites iliacoides Composite Assemblage Zone of Vigran et al. (2014), which is correlated with the base of the Ladinian Stage. On central Spitsbergen, rare occurrences of Triadispora verrucata are known from the late Anisian Protodiploxypinus decus Composite Assemblage Zone (Vigran et al. 2014, p. 98). Similarly, Paterson and Mangerud (2017) recorded specimens of Triadispora verrucata from the middle Anisian Triadispora obscura Composite Assemblage in exploration wells from the southern Barents Sea.

The FO of consistent Triadispora verrucata is taken here as the base of the Ladinian.

\section{FO of Ovalipollis pseudoalatus}

The FO of Ovalipollis pseudoalatus is based on multiple records from the Norwegian Arctic. The species was recorded in all three Ladinian cores in the Svalis Dome, Barents Sea (Vigran et al. 1998). Its base corresponds approximately to the base of the Echinitosporites iliacoides Composite Assemblage Zone of Vigran et al. (2014), the base of which is set at the base of the Ladinian. An FO of Ovalipollis pseudoalatus at the base Ladinian was also reported by Hochuli et al. (1989).

The FO of Ovalipollis pseudoalatus is taken here as the base of the Ladinian.

\section{FO of consistent Staurosaccites quadrifidus}

The FO of consistent Staurosaccites quadrifidus is based on multiple records from the Norwegian Arctic. The species was recorded in all three Ladinian cores in the Svalis Dome, Barents Sea (Vigran et al. 1998). Its base corresponds approximately to the base of the Echinitosporites iliacoides Composite Assemblage Zone of Vigran et al. (2014), which is set at the base of the Ladinian. We note that rare older occurrences of Staurosaccites quadrifidus have been reported from assemblages assigned to the early Anisian Anapiculatisporites spiniger Composite Assemblage Zone, for example from western Spitsbergen and Barentsøya (Vigran et al. 2014). Elsewhere, Paterson and Mangerud (2017) recorded rare specimens of Staurosaccites quadrifidus from the late Anisian Protodiploxypinus decus Composite Assemblage Zone in exploration wells from the southern Barents Sea.

The FO of consistent Staurosaccites quadrifidus is taken here as the base of the Ladinian.

\section{FO of common to abundant Semiretisporis hochulii}

The FO of common to abundant Semiretisporis hochulii is based on multiple records from the Norwegian Arctic. The taxon has variously been reported informally in the literature as Semiretisporis "barentszi" (van Veen 1985), Semiretisporis sp. A (Vigran et al. 1998, pl. 9, fig. 2), Semiretisporis sp. 1 (Hounslow et al. 2008, fig. 7) and Semiretisporis sp. A ("barentzii") (Vigran et al. 2014). The species was formally described as Semiretisporis hochulii by Paterson and Mangerud (2019). Vigran et al. (1998) recorded it from the base of their oldest Ladinian core at the Svalis Dome, Barents Sea, co-occurring with Echinitosporites iliacoides. Paterson et al. (2018) recorded common Semiretisporis hochulii from the lower part of the De Geerdalen Formation at Sentralbanken.

The FO of common to abundant Semiretisporis hochulii is taken here as the base of the Ladinian. 


\section{FO of sporadic Enzonalasporites vigens}

The FO of sporadic Enzonalasporites vigens is based on multiple records from the Norwegian Arctic, including several localities on Svalbard (Vigran et al. 2014). Hochuli et al. (1989) also reported Enzonalasporites vigens in their early Carnian Assemblage "F". Vigran et al. (2014) reported the $\mathrm{FO}$ of Enzonalasporites vigens from the base of their Aulisporites astigmosus Composite Assemblage Zone, corresponding to the base of the Carnian. While most typical of the early Carnian succession, rare occurrences of the taxon have been recorded in assemblages assigned to the Ladinian Echitosporites iliacoides Composite Assemblage Zone from Spitsbergen and the Barents Sea (Vigran et al. 2014).

The FO of Enzonalasporites vigens is taken here as the base of the Carnian.

\section{FO of sporadic Camerosporites secatus}

The FO of sporadic Camerosporites secatus is based on multiple records from the Norwegian Arctic. Vigran et al. (2014) recorded the species from the base of their Aulisporites astigmosus Composite Assemblage Zone, corresponding to the base of the Carnian Stage.

The FO of Camerosporites secatus is taken here as the base of the Carnian.

\section{FO of consistent Aulisporites astigmosus}

The FO of consistent Aulisporites astigmosus is based on multiple records from the Norwegian Arctic. Vigran et al. (2014) recorded the species from the base of their Aulisporites astigmosus Composite Assemblage Zone, corresponding to the base of the Carnian. Hochuli et al. (1989) also reported Aulisporites astigmosus in their early Carnian Assemblage "F", while Mueller et al. (2016) designated their Aulisporites astigmosus pollen assemblage zone as Julian 2 (lower Carnian), integrated with organic-carbon isotope data linked to the geomagnetic polarity time scale. Paterson et al. (2017) recorded Aulisporites astigmosus from an early Carnian core drilled in the Snadd Formation of off-shore Kong Karls Land; this occurrence is constrained by Re-Os geochronology from an underlying core at the same site. While generally typical of the early Carnian, Aulisporites astigmosus may have sporadic occurrences in the Echinitosporites iliacoides and the Protodiploxypinus decus composite assemblage zones of Ladinian and late Anisian age respectively (Vigran et al. 2014).

The FO of consistent Aulisporites astigmosus is taken here as the base of the Carnian.

\section{LO of sporadic Cordaitina gunyalensis}

The LO of sporadic Cordaitina gunyalensis is based on multiple records from the Norwegian Arctic, including Vigran et al. $(1998,2014)$ from the Svalis Dome, Barents Sea, where it was recorded in three Ladinian cores. No independent faunal evidence exists from the three Ladinian cores, but the cored intervals overlie upper Anisian successions dated by ammonoids. Occurrences of Cordaitina gunyalensis in shallow cores penetrating the Snadd Formation in the Sentralbanken High and offshore Kong Karls Land areas of the Barents Sea indicate a LO within the lower part of the Aulisporites astigmosus Composite Assemblage Zone. Rhenium-osmium geochronology from the latter location (Xu et al. 2014), indicates that the LO of Cordaitina gunyalensis is no older than earliest Carnian. On Spitsbergen, the species so far has not been reported above the Anisian, and its absence within Carnian strata may be due to poor preservation.

The LO of Cordaitina gunyalensis is taken here as $10 \%$ up from the base of the Carnian.

\section{LO of Echinitosporites iliacoides}

The LO of Echinitosporites iliacoides is based on multiple records from the Norwegian Arctic. It was recorded at Bjørnøya in beds with the ammonoid Daxatina cf. canadensis (Mørk et al. 1990), which is of early Carnian age. This horizon would previously have been placed in the Ladinian, but the base of the Carnian has been designated a GSSP defined by the lowest occurrence of the cosmopolitan ammonoid Daxatina (base of Daxatina canadensis Subzone, lowest subzone of Trachyceras Zone) (Gradstein et al. 2012). Hochuli et al. (1989) used the LO of Echinitosporites iliacoides as a good downhole marker, and Vigran et al. (2014) recorded it from various locations in the Norwe-gian Arctic. Paterson and Mangerud (2017, 2019) and Paterson et al. (2017) recorded it from several places in the Barents Sea.

The LO of Echinitosporites iliacoides is here taken as 10\% up from the base of the Carnian.

\section{LO of common Semiretisporis hochulii}

The LO of Semiretisporis hochulii is based on multiple records from the Norwegian Arctic. It was noted by Mueller et al. (2016) from the lower De Geerdalen Formation in Spitsbergen. Paterson et al. (2018) recorded common occurrences of the taxon (as Semiretisporis sp. A) (in their Assemblage SBH-1) from cores in the lower De Geerdalen Formation in the Sentralbanken area, having the LO of its common occurrence coeval with the LO of Echinitosporites iliacoides. Paterson and Mangerud (2017) also recorded that this LO is coeval with the top of Echinitosporites iliacoides in the lowermost Snadd Formation (in their assemblage SBS-VII); they correlated it with Assemblage G of Hochuli et al. (1989), which is now assigned to the early Carnian based on new ammonoid evidence (see Vigran et al. 2014 for discussion). The LO of common Semiretisporis hochulii marks the top of Semiretisporis hochulii Zone of Paterson and Mangerud (2019).

The LO of common to abundant Semiretisporis hochulii is taken here as $10 \%$ up from the base of the Carnian. 


\section{FO of common Podosporites vigraniae}

The FO of common Podosporites vigraniae is based on multiple records from the Norwegian Arctic. The age assignment of this event approximately corresponds to the LO of Echinitosporites iliacoides, which is recorded in beds containing the early Carnian ammonoid Daxatina cf. canadensis (Mørk et al. 1990). Paterson and Mangerud (2019) described the Podosporites vigraniae Zone, originally described as the "Podosporites cf. amicus Assemblage" (Paterson et al. 2016). They recorded this taxon from the Snadd Formation at core 7534/4-U-1, Sentralbanken High, Barents Sea.

The FO of common Podosporites vigraniae is taken here as $10 \%$ up from the base of the Carnian.

\section{FO of sporadic Ricciisporites tuberculatus}

The FO of sporadic Ricciisporites tuberculatus is based on multiple records from the Norwegian Arctic. Vigran et al. (2014) reported its FO as somewhat above the base of their Aulisporites astigmosus Composite Assemblage Zone and included it as part of the definition of that zone. The age assignment of this event approximately corresponds to the LO of Echinitosporites iliacoides, which is recorded in beds containing the early Carnian ammonoid Daxatina cf. canadensis (Mørk et al. 1990). Paterson and Mangerud (2017) recorded Ricciisporites tuberculatus in exploration wells from the Barents Sea, but not extending down to the LO of Echinitosporites ilicoides; the same is the case from the Sentralbanken area (Paterson et al. 2017). However, rare specimens have been recorded from the Ladinian Kobbe and Snadd formations, assigned to the Echinitosporites iliacoides Composite Assemblage Zone, in the southern Barents Sea (Vigran et al. 2014).

The FO of sporadic Ricciisporites tuberculatus is taken here as $10 \%$ up from the base of the Carnian.

\section{FO of consistent Camarozonosporites rudis}

The FO of consistent Camarozonosporites rudis is based on multiple records from the Norwegian Arctic. Vigran et al. (2014) recorded it somewhat above the base of, and as part of the definition of, their Aulisporites astigmosus Composite Assemblage Zone. Paterson and Mangerud (2015) recorded it ranging throughout the De Geerdalen Formation on Hopen. From the Kong Karls Land area, Paterson et al. (2017) recorded it throughout an early Carnian core drilled in the Snadd Formation constrained by Re-Os geochronology from an underlying core at this site. The age assignment of the consistent FO of Camarozonosporites rudis corresponds approximately to the LO of Echinitosporites iliacoides, which is calibrated to beds with the early Carnian ammonoid Daxatina cf. canadensis (Mørk et al. 1990). However, sporadic occurrences of Camarozonosporites rudis have been recorded in Barents Sea wells from the Anisian Kobbe and Steinkobbe formations, corresponding with the
Protodiploxypinus decus (Vigran et al. 2014, p. 138, 140) and Triadispora obscura (Paterson and Mangerud 2017) composite assemblage zones.

The FO of consistent Camarozonosporites rudis is taken here as $10 \%$ up from the base of the Carnian.

\section{FO of rare Uvaesporites argentaeformis}

The FO of rare Uvaesporites argentaeformis is based on multiple records from the Norwegian Arctic. Vigran et al. (2014) listed the species as appearing somewhat above the base of, but part of the definition of, their Aulisporites astigmosus Composite Assemblage Zone, to which they assigned an early to middle Carnian age. Paterson and Mangerud (2015) recorded rare Uvaesporites argentaeformis through the De Geerdalen Formation at Hopen, but did not record the range base because the base of the formation there is below sea level. The age assignment approximately corresponds to, or is close to, the LO of Echinitosporites iliacoides, which has a LO in beds with the early Carnian ammonoid Daxatina cf. canadensis (Mørk et al. 1990).

The FO of rare Uvaesporites argentaeformis is taken here as $10 \%$ up from the base of the Carnian.

\section{FO of Kyrtomisporis moerki}

This recently described taxon was previously recorded as Kyrtomisporis sp. A by Paterson et al. (2017, pl. 2, figs. 1215) throughout an early Carnian core from the Snadd Formation in the Kong Karls Land area; the age is constrained by $\mathrm{Re}-\mathrm{Os}$ geochronology from an underlying core at the site. The age assignment of the FO of Kyrtomisporis moerki corresponds approximately to, or near the FO of, Echinitosporites iliacoides in this core. It was later recorded from a core in the middle part of the De Geerdalen Formation in the Sentralbanken area (Paterson et al. 2018). Its short range makes it a very good marker, and it is a diagnostic component of the Podosporites vigraniae Zone of Paterson and Mangerud (2019).

The FO of Kyrtomisporis moerki is taken here as $10 \%$ up from the base of the Carnian.

\section{LO of Kyrtomisporis moerki}

Kyrtomisporis moerki (Kyrtomisporis sp. A of Paterson et al. 2017, pl. 2, figs. 12-15) was recorded throughout an early Carnian core from the Snadd Formation in the Kong Karls Land area; the age is constrained by Re-Os geochronology from an underlying core at the site. Kyrtomisporis moerki has so far not been recorded above the early Carnian. It was also recorded from a core in the middle part of the De Geerdalen Formation in the Sentralbanken area (Paterson et al. 2018). Its short range makes it a very good marker species.

The LO of Kyrtomisporis moerki is taken here as the base of the Tuvalian (upper Carnian). 


\section{FO of consistent Kyrtomisporis spp.}

The FO of consistent Kyrtomisporis spp. (Kyrtomisporis laevigatus, Kyrtomisporis gracilis and Kyrtomisporis speciosus) is based on multiple records in the Norwegian Arctic. The FOs of these taxa were recorded by Bjærke and Manum (1977) and Paterson and Mangerud (2015) from upper De Geerdalen Formation (Hopen Member; Lord et al. 2014) at Hopen. On Spitsbergen, Mueller et al. (2016) recorded the FO of Kyrtomisporis spp. somewhat below the Leschikisporis aduncus acme. The base of Kyrtomisporis spp. in the Sverdrup Basin is still unknown, but their occurrence was reported by Suneby and Hills (1988) in younger Triassic successions. Older occurrences of Kyrtomisporis laevigatus might represent misidentifications of Concavisporites crassexinus, Dictyophyllidites mortonii or Iraqispora labrata.

The FO of consistent Kyrtomisporis spp. (Kyrtomisporis laevigatus, Kyrtomisporis gracilis and Kyrtomisporis speciosus) is taken here as the base of the Tuvalian (upper Carnian).

\section{LO of Dyupetalum vicentinense}

The LO of Dyupetalum vicentinense is based on multiple records from the Norwegian Arctic. Although rare, it is recorded in many localities; its youngest occurrence was regarded as intra-Ladinian by Hochuli et al. (1989). However, rare specimens were recorded in younger successions by Paterson et al. (2017), from shallow-core material in the Snadd Formation, offshore Kong Karls Land. Rheniumosmium geochronology from other cores in the region (Xu et al. 2014) indicate an age no older than earliest Carnian. Similarly, early Carnian occurrences have been noted in exploration wells and shallow stratigraphic cores from the southern Barents Sea and Sentralbanken High, respectively (Paterson and Mangerud 2017, Paterson et al. 2018).

The LO of Dyupetalum vicentinense is taken here as the base of the Tuvalian (upper Carnian).

\section{FO of dominant Leschikisporis aduncus}

The FO of dominant Leschikisporis aduncus is based on multiple records from the Norwegian Arctic. Bjærke and Manum (1977) first recorded this acme from outcrop sections on Hopen, and later Paterson and Mangerud (2015) and Paterson et al. (2015) recorded it from the middle De Geerdalen Formation, also from Hopen, approximately dated as late Carnian. Hochuli et al. (1989) noted that Leschikisporis aduncus is common in their "middle" Carnian Assemblage D. In Spitsbergen, Nagy et al. (2011), Vigran et al. (2014) and Mueller et al. (2014, 2016) recorded this event from the upper parts of the De Geerdalen Formation. This event is also recognized in cores from Sentralbanken area of the Barents Sea (Paterson et al. 2018) and in exploration wells (e.g., Hochuli and Vigran 2010; Vigran et al. 2014; Paterson and Mangerud 2017, 2019). Note that Paterson et al. (2017) recorded abundant, but not dominant, Leschikisporis aduncus in an early Carnian core drilled in the Snadd Formation from offshore Kong Karls Land. These Snadd Formation assemblages were more diverse and different from those on Hopen, which were totally dominated by Leschikisporis aduncus. The former are probably of older, early Carnian age, as they are constrained by Re-Os geochronology from an underlying core.

The FO of dominant Leschikisporis aduncus is taken here as the base of the Tuvalian (upper Carnian).

\section{FO of abundant Protodiploxypinus}

The FO of abundant Protodiploxypinus is based on multiple records from the Norwegian Arctic. It was recorded by Paterson and Mangerud (2015) from the upper De Geerdalen Formation (Hopen Member) on Hopen. They named their Protodiploxypinus Assemblage from this acme and assigned it a late Carnian (Tuvalian) age (see discussion in Paterson and Mangerud 2015). This event is also recognized in cores from Sentralbanken area in the Barents Sea (Paterson et al. 2018), and from exploration wells in the upper Snadd Formation in the southern Barents Sea (Hochuli and Vigran 2010; Paterson and Mangerud 2017, 2019).

The FO of abundant Protodiploxypinus is taken here as the base of the Tuvalian (upper Carnian).

\section{LO of dominant Leschikisporis aduncus}

The LO of abundant to dominant Leschikisporis aduncus is based on multiple records from the Norwegian Arctic. Paterson and Mangerud (2015) recorded this event in the De Geerdalen Formation, where Leschikisporis aduncus is abundant up to the base of the Hopen Member. They defined their Leschikisporis aduncus Assemblage partly from this event and assigned it a late Carnian (middle Tuvalian) age (see Paterson and Mangerud 2015). Nagy et al. (2011) recorded this event from the upper part of the same formation in Spitsbergen. It is also recognized as an important event in Barents Sea exploration wells (e.g., Hochuli and Vigran 2010; Vigran et al. 2014; Paterson and Mangerud 2017). As discussed by Paterson et al. (2018), the apparent lack of Leschikisporis aduncus in the Sverdrup Basin may be because the Carnian samples analyzed from wells in the Schei Point Formation (Fisher and Bujak 1975) are younger than the Leschikisporis aduncus acme. In the Russian Barents Sea, this taxon remains dominant until the Norian (Mørk et al. 1993), suggesting that its range top in the Norwegian Barents Sea is facies controlled (see Paterson et al. 2016 and Paterson and Mangerud 2019). Note that the LO of abundant to dominant Leschikisporis aduncus is corresponding the the FO, indicating that this was a short-lived event.

The LO of dominant Leschikisporis aduncus is taken here to correspond to the base of the Tuvalian (upper Carnian).

\section{FO of rare Rhaetogonyaulax}

The FO of rare Rhaetogonyaulax (including Rhaetogonyaulax 
arctica and Rhaetogonyaulax rhaetica) is based on multiple records from the Norwegian Arctic. This includes records from the middle parts of the De Geerdalen Formation dated as late Carnian (Paterson and Mangerud 2015, 2019 and Paterson et al. 2016). Rhaetogonyaulax has been recorded in the Sverdrup Basin (Fisher and Bujak 1975; Bujak and Fisher 1976; Felix and Burbridge 1978) and Alaska (Wiggins 1973).

The FO of rare Rhaetogonyaulax is taken here as the base of the Tuvalian (upper Carnian).

\section{LO of consistent Schizaeoisporites worsleyi}

The LO of consistent Schizaeoisporites worsleyi is based on multiple records from the Norwegian Arctic. This species was first described from the Carnian on Hopen (Bjærke and Manum 1977). Paterson and Mangerud (2015) later recorded it ranging to the top of the De Geerdalen Formation, just below the overlying ammonoid-dated Norian succession. Vigran et al. (1998) recorded it from three Ladinian cores in the Svalis Dome, Barents Sea. Vigran et al. (2014) found rare occurrences of Schizaeoisporites worsleyi in their Limbosporites lundbladiae Composite Assemblage Zone, which may be reworked. Schizaeoisporites worsleyi is generally recorded in low numbers, but it is very distinct and thus a good marker.

The LO of consistent Schizaeoisporites worsleyi is taken here as the base of the Norian.

\section{LO of sporadic Aulisporites astigmosus}

The LO of sporadic Aulisporites astigmosus is based on multiple records from the Norwegian Arctic. Paterson and Mangerud (2015) recorded this species from the De Geerdalen Formation, occurring up to the base of the Hopen Member on Hopen. Vigran et al. (2014) defined an early to middle Carnian Aulisporites astigmosus Composite Assemblage zone. However, Paterson et al. (2018) refined the palynological zonation and verified the palynological division between the lower and middle Carnian suggested by Hochuli et al. (1989), designating zones SBH I to SBH III.

The LO of sporadic Aulisporites astigmosus is taken here as the base of the Norian.

\section{LO of abundant Protodiploxypinus}

The LO of abundant Protodiploxypinus is based on multiple records from the Norwegian Arctic. It was first recorded as a reliable first downhole occurrence by Hochuli et al. (1989), and as a typical component of their late Carnian Assemblage C. Protodiploxypinus was also recorded by Paterson and Mangerud (2015) from the upper De Geerdalen Formation (Hopen Member) at Hopen. They named their Protodiploxypinus Assemblage from this acme and assigned it to the latest Carnian (see discussion in Paterson and Mangerud 2015). Paterson and Mangerud (2017) recorded abundant Protodiploxypinus from explor- ation wells in the upper Snadd Formation in the Barents Sea.

The LO of abundant Protodiploxypinus is taken here as the base of the Norian.

\section{LO of consistent Illinites chitonoides}

The LO of consistent Illinites chitonoides is based on multiple records from the Norwegian Arctic. It was reported from within the middle De Geerdalen Formation by Vigran et al. (2014). However, Paterson and Mangerud (2015) recorded it to the top of the De Geerdalen Formation (i.e. top Hopen Member) on Hopen, a horizon that they assigned a latest Carnian (Tuvalian) age. Paterson et al. (2018) recorded sporadic occurrences of Illinites chitonoides up into the early Norian Flatsalen Formation in cores from the Sentral-banken High, Barents Sea.

The LO of consistent Illinites chitonoides is taken here as the base of the Norian.

\section{FO of common Rhaetogonyaulax}

The FO of common Rhaetogonyaulax (including Rhaetogonyaulax arctica and Rhaetogonyaulax rhaetica) is based on multiple records from the Norwegian Arctic (Mangerud et al. 2018). Paterson and Mangerud (2015) and Paterson et al. (2016) recorded common Rhaetogonyaulax from the base of the Flatsalen Formation, where ammonoids of the ammonoid Mojsisovicsites kerri Zone of Norian age are recorded. Note that on Hopen, the Rhaetogonyaulax arctica peak is older than the Rhaetogonyaulax rhaetica peak. However, we consider that the difference reflects paleoenvironmental conditions rather than stratigraphic range. Rhaetogonyaulax arctica favours conditions closer to shore, and is thus more abundant than Rhaetogonyaulax rhaetica during the early stages of a transgression. Rhaetogonyaulax rhaetica probably favours outer shelf settings because it is most abundant in association with maximum flooding surfaces (Paterson et al. 2016). This interpretation is consistent with the overall lower abundance of Rhaetogonyaulax rhaetica in more proximal localities in the Barents Sea area, as in the Nordkapp Basin (Paterson et al. 2018) and Sentralbanken area (Paterson et al. 2017). One of us (JB; Appendix C) has also recorded the FO of common Rhaetogonyaulax rhaetica in Norian sidewall core sample $9188 \mathrm{ft}(2801 \mathrm{~m})$ in the Fireweed 1 well off northern Alaska; the age is based on the occurrence of age-diagnostic miospores in the same interval.

The FO of common Rhaetogonyaulax is taken here as the base of the Norian.

\section{FOs of Hebecysta, Heibergella, Noricysta and Sverdrupiella}

The FOs of dinocysts Hebecysta brevicornuta, Heibergella aculeata, Heibergella asymmetrica, Heibergella salebrosacea, Noricysta fimbriata, Noricysta pannucea, Noricysta varivallata, Sverdrupiella baccata, Sverdrupiella manicata, Sverdrupiella mutabilis, Sverdrupiella ornaticingulata, 
Sverdrupiella raiaformis, Sverdrupiella sabinensis, Sverdrupiella septentrionalis, Sverdrupiella spinosa, and Sverdrupiella usitata are based on their occurrences in the oldest Norian sample (sidewall core $9188 \mathrm{ft} ; 2801 \mathrm{~m}$ ) in the Fireweed 1 exploration well, offshore northern Alaska. The sample is dated as Norian based on associated miospore events shown for the well in Appendix C herein. The dinocyst species were originally described by Bujak and Fisher (1976) in eight Sverdrup Basin well sections that were assigned a Norian age based on associated miospore assemblages by Fisher and Bujak (1975). They also characterize strata dated as Norian based on associated miospore events in exploration wells Klondike OCS-Y-1482 (Chukchi Sea) and Romulus C-67 (Sverdrup Basin), but the absence of sidewallor conventional-core samples in these wells precludes confident age assignment of their oldest occurrences.

Species of Hebecysta, Heibergella, Noricysta and Sverdrupiella are restricted to the Noricysta pannucea Heibergella asymmetrica (PA) Subzone of the Triancoraesporites ancorae - Camarozonsporites laevigatus (AL) Zone of Suneby and Hills (1988). The PA Subzone occurs in the lower part of the Romulus Member of the Heiberg Formation exposed at McKinley Bay, Blackwelder Anticline, Fosheim Anticline and Raanes Peninsula on Elsemere Island, in strata assigned a Norian age by Embry (1982) based on bivalves and ammonoids.

Paterson and Mangerud (2015) recorded rare Sverdupiella from the base of the Flatsalen Formation on Hopen, where taxa of the Norian ammonoid Mojsisovicsites kerri Zone are recorded. As with Rhaetogonyalaux, the stratigraphic range of Sverdrupiella in the circum-Arctic region likely varies according to paleoenvironment: the genus is apparently more common and diverse in the Sverdrup Basin as shown above (e.g., Bujak and Fisher 1976; Suneby and Hills 1988), which was likely in closer communication with the open ocean compared to the Barents Sea area (Sømme et. al. 2018).

The FO of Hebecysta, Heibergella, Noricysta, Sverdrupiella is taken here as the base of the Norian.

\section{FO of Classopollis torosus}

The FO of Classopollis torosus is based on multiple records from the Norwegian Arctic. It is recorded from the base of the Flatsalen Formation on Hopen, a horizon assigned an early Norian age based on ammonoids typical of the Mojsisovicsites kerri Zone (Paterson and Mangerud 2015). The taxon also gave its name to Paterson and Mangerud's Classopollis torosus Assemblage. Classopollis torosus was previously recorded by Smith et al. (1975) and Bjærke and Manum (1977) from Hopen Island. Paterson et al. (2017) reported the FO of Classopollis torosus in their Norian SBH-V Assemblage from Sentralbanken in the Barents Sea. Paterson and Mangerud (2017) reported common Classopollis torosus in their Norian Assemblage SBS-II based on exploration wells in the southern Barents Sea. In the Russian Barents Shelf, a similar influx in Classopollis is recorded at the base of the Norian T3k-n Zone (Fefilova
1988; Pavlov et al. 1985; Mørk et al. 1993).

The FO of Classopollis torosus is taken here as the base of the Norian.

\section{FO sporadic Limbosporites lundbladiae}

The FO of sporadic Limbosporites lundbladiae is based on records from multiple localities in the Arctic; although relatively rare in the Norian, it seems to be a robust marker. Fisher and Bujak (1975) reported Limbosporites lundbladiae co-occurring with dinoflagellate-cyst assemblages typical for the Norian successions in the Sverdrup Basin, but their work was based mainly on cuttings samples, so that taxon bases are unreliable. Working on out-crop sections in the Sverdrup Basin, Suneby and Hills (1988) recorded Limbosporites lundbladiae ranging from within their oldest Norian SC Subzone in the Heiberg Formation, but did not study older sections to verify the true FO. From the Barents Sea area, Hochuli et al. (1989) reported the $\mathrm{FO}$ of Limbosporites lundbladiae in their Assemblage B-2 and Vigran et al. (2014) used the FO of this species as the base of their Norian Limbosporites lundbladiae Composite Assemblage Zone. Paterson and Mangerud (2015) also used the FO of abundant Limbosporites lundbladiae to define the base of their Limbosporites lundbladiae - Quadraeculina anellaeformis Assemblage, corresponding to basal Flatsalen Formation on Hopen, which is assigned an early Norian age based on ammonoids; however, Limbosporites lundbladiae occurs sporadically from the base of the Flatsalen Formation. Paterson et al. (2017) recorded a few specimens of Limbosporites lundbladiae from the uppermost De Geerdalen Formation from shallow cores in the Sentralbanken area; this occurrence is close to the Carnian/Norian transition.

The FO of sporadic Limbosporites lundbladiae is taken here as the base of the Norian.

\section{FO of sporadic Quadraeculina anellaeformis}

The FO of sporadic Quadraeculinaanellaeformis is reported from multiple localities in the Arctic. Suneby and Hills (1988) recorded Quadraeculina anellaeformis ranging from within their oldest Norian SC Subzone in the Heiberg Formation, Sverdrup Basin; however, the FO is unknown, and the species ranges up into the Jurassic. From the Barents Sea area, Hochuli et al. (1989) reported the FO of Quadraeculina anellaeformis in their Assemblage B-2, while Vigran et al. (2014) reported the species from the base of their Limbosporites lundbladiae Composite Assemblage Zone, which corresponds to the base of the Norian. Paterson and Mangerud (2015) recorded the FO of sporadic Quadraeculina anellaeformis from the basal Flatsalen Formation on Hopen, a horizon assigned an early Norian age based on ammonoids typical of the Mojsisovicsites kerri Zone (Paterson and Mangerud 2015). However, Quadraeculina anellaeformis occurred more consistently from the base of the overlying Svenskøya Formation, from which they defined their Limbosporites lundbladiae - 
Quadraeculina anellaeformis Assemblage. Older rare occurrences of Quadraeculina anellaeformis have been recorded from the De Geerdalen Formation (Mueller et al. 2016) and in strata dated as late Carnian in cores from the Sentralbanken High area of the Barents Sea (Paterson et al. 2018).

The FO of sporadic Quadraeculina anellaformis is taken here as the base of the Norian.

\section{FO of consistent Riccisporites tuberculatus}

The FO of consistent (to abundant) Riccisporites tuberculatus is based on records from Suneby and Hills (1988). However, Felix (1975) first recognized Riccisporites tuberculatus as an important stratigraphic marker in the Heiberg Formation on Ellef Ringnes Island, Sverdrup Basin. He reported abundant Riccisporites tuberculatus in all samples from the Triassic part of the formation. Later, Suneby and Hills (1988) reported Riccisporites tuberculatus from the base of their studied section (AL Biozone), dated as early Norian. From farther south, in East Greenland, Pedersen and Lund (1980) and Mander et al. (2013) recorded abundant Riccisporites tuberculatus from the Kap Stewart Formation, a classic Rhaetian plant-macrofossil locality, but most likely representing a mixed flora. Paterson et al. (2017) reported Riccisporites tuberculatus from the basal Flatsalen Formation equivalent, based on core material from the Sentralbanken area, Barents Sea. On nearby Hopen Island, the lower part of the Flatsalen Formation was dated as early Norian based on ammonoids. Although the age of this FO is somewhat uncertain, its consistent FO is inferred to be at the base of the Norian.

FO of consistent Riccisporites tuberculatus is here taken here as the base of the Norian.

\section{LO of Kraeuselisporites cooksoniae}

The LO of Kraeuselisporites cooksoniae is based on records by Paterson and Mangerud (2015) from Hopen, where this taxon was recorded to the top of the Flatsalen Formation; its LO is coeval with that of the dinoflagellate cyst Rhaetogonyaulax, occurring slightly above early Norian ammonoids.

The LO of Kraeuselisporites cooksoniae is taken here as $50 \%$ up from the base of the Norian.

\section{LO of Porcellispora longdonensis}

The LO of Porcellispora longdonensis is based on data from Paterson and Mangerud (2015) from Hopen Island, where this taxon ranges to the top of the Flatsalen Formation, its LO being coeval with the LO of Rhaetogonyaulax. The LO of Porcellispora longdonensis occurs somewhat above early Norian ammonoids, but still below typical Rhaetian palynological assemblages at this location. A few specimens are reported in younger sections in the Hammerfest Basin (Vigran et al. 2014) and in the Sverdup Basin (Suneby and Hills 1988).

The LO of Porcellispora longdonensis is taken here as 50\% up from the base of the Norian.

\section{FO of consistent Limbosporites lundbladiae}

The FO of consistent Limbosporites lundbladiae is based on multiple reports from the Arctic and seems to be a robust marker. From outcrop sections in the Sverdrup Basin, Suneby and Hills (1988) recorded common Limbosporites lundbladiae from outcrop sections above typical Norian dino flagellate cyst assemblages and ranging up from within their oldest Norian SC Subzone in the Heiberg Formation, but with the FO unknown. Felix (1975) and Fisher and Bujak (1975) also reported Limbosporites lundbladiae but did not provide quantitative data. Hochuli et al. (1989) reported the lowest occurrence of Limbosporites lundbladiae in their Assemblage B-2. Vigran et al. (2014) named their Norian palynological zone the Limbosporites lundbladiae Compos-ite Assemblage Zone and defined the base of the zone on the FO of the species, equating the event with the base of the Norian. Paterson and Mangerud (2015) recorded the consistent FO of Limbosporites lundbladiae from the base of the Svenskøya Formation at Hopen and defined the base of their Limbosporites lundbladiae - Quadraeculina anellaeformis Assemblage at this level. They assigned to the event a ?late Norian age based on palynological evidence in combination with the age assignment of the underlying assem-blages. Pedersen and Lund (1980) also recorded abundant Limbosporites lundbladiae from the Kap Stewart Formation of East Greenland. Since independent age control is very limited in this part of the succession, age determination is problematic.

The FO of consistent Limbosporites lundbladiae is taken here as $50 \%$ up from the base of the Norian.

\section{FO of consistent Quadraeculina anellaeformis}

The FO of consistent (to common) Quadraeculina anellaeformis has been reported from multiple localities in the Arctic. From outcrop sections, Suneby and Hills (1988) reported Quadraeculina anellaeformis as ranging from within their oldest Norian SC Subzone in the Heiberg Formation, albeit with an unknown FO as they did not include older successions. They recorded Quadraeculina anellaeformis ranging up into the Jurassic. Paterson and Mangerud (2015) defined the base of their Limbosporites lundbladiae - Quadraeculina anellaeformis Assemblage as corresponding to the basal Svenskøya Formation, with Quadraeculina anellaeformis be-ing common in the upper part of the formation. The species has also been recorded as common from the Knorringfjellet Formation in Spitsbergen (Mueller et al. 2016).

The FO of consistent Quadraeculina anellaeformis is taken here as $50 \%$ up from the base of the Norian.

\section{FO of common Riccisporites tuberculatus}

The FO of common to abundant Riccisporites tuberculatus is based on Suneby and Hills (1988), but the species was first recognized as an important stratigraphic marker by Felix (1975) in materials from Ellef Ringnes Island, Sverdrup 
Basin. He reported this species as abundant in all samples from the Triassic part of the Heiberg Formation. Suneby and Hills (1988) reported its common occurrence from the Heiberg Formation at the base of their LT Biozone, which is of latest Norian to early Rhaetian age. In the Barents Sea region, the FO of common Ricciisporites tuberculatus occurs above early Norian ammonoids and below typical Rhaetian palynological assemblages.

The FO of common Riccisporites tuberculatus is taken here as $50 \%$ up from the base of the Norian.

\section{FO of Polycingulatisporites crenulatus}

Paterson and Mangerud (2015) reported Polycingulatisporites crenulatus from the upper part of the Svenskøya Formation on Hopen, and tentatively correlated it with Assemblage A of Hochuli et al. (1989). It is a rare, but very distinct taxon, and its FO is probably of stratigraphic significance. As it co-occurs with the typical Triassic palynomorph Aratrisporites in "typical Rhaetian" palynological assemblages distinct from those in older strata, a Rhaetian age is inferred.

The FO of Polycingulatisporites crenulatus is taken here as the base of the Rhaetian.

\section{LOs of Hebecysta, Heibergella, Noricysta and Sverdrupiella excluding Sverdrupiella mutabilis}

The LOs of dinocysts Hebecysta brevicornuta, Heibergella aculeata, Heibergella asymmetrica, Heibergella salebrosacea, Noricysta fimbriata, Noricysta pannucea, Noricysta varivallata, Sverdrupiella baccata, Sverdrupiella manicata, Sverdrupiella ornaticingulata, Sverdrupiella raiaformis, Sverdrupiella sabinensis, Sverdrupiella septentrionalis, Sverdrupiella spinosa, and Sverdrupiella usitata are based on their occurrence in the youngest samples dated as Norian in exploration wells Fireweed 1 (offshore northern Alaska), Klondike OCS-Y-1482 (Chukchi Sea) and Romulus C-67 (Sverdrup Basin). This date is interpreted from miospore events that occur in the well sections (Appendix C). The dinocyst species are restricted to the Noricysta pannucea - Heibergella asymmetrica (PA) Subzone of the Triancoraesporites ancorae - Camarozonsporites laevigatus (AL) Zone defined by Suneby and Hills (1988). The PA Subzone occurs in the lower part of the Romulus Member of the Heiberg Formation exposed at McKinley Bay, Blackwelder Anticline, Fosheim Anticline and Raanes Peninsula on Elsemere Island in strata assigned a Norian age by Embry (1982) based on bivalves and ammonoids.

The LOs of Hebecysta brevicornuta, Heibergella aculeata, Heibergella asymmetrica, Heibergella salebrosacea, Noricysta fimbriata, Noricysta pannucea, Noricysta varivallata, Sverdrupiella baccata, Sverdrupiella manicata, Sverdrupiella ornaticingulata, Sverdrupiella raiaformis, Sverdrupiella sabinensis, Sverdrupiella septentrionalis, Sverdrupiella spinosa, and Sverdrupiella usitata are taken here as the base of the Rhaetian.

\section{LO of Ricciisporites umbonatus}

The LO of Ricciisporites umbonatus was reported by Suneby and Hills (1988) to occur slightly below the LO of Limbosporites lundbladiae and to be coeval with the LO of common Limbosporites lundbladiae and Ricciisporites tuberculatus. Vigran et al. (2014) also reported this event as intra-Rhaetian. Precise age assignment is difficult, but a relative occurrence of this event can be proposed based on experience.

The LO of Ricciisporites umbonatus is taken here to be $30 \%$ up from the base Rhaetian.

\section{LO of common Limbosporites lundbladiae}

Suneby and Hills (1988) reported the LO of common Limbosporites lundbladiae at the top of their Limbosporites lundbladiae - Ricciisporites tuberculatus Biozone and suggested its age is latest Norian or early Rhaetian. However, they indicated uncertainty regarding the age assignment. Vigran et al. (2014) reported the LO of common Limbosporites lundbladiae as an intra-Rhaetian event. Paterson and Mangerud (2015) defined their Limbosporites lundbladiae - Quadraeculina anellaeformis Assemblage from the Svenskøya Formation and recorded common Limbosporites lundbladiae to the top of the formation. Since there have been no reports of Limbosporites lundbladiae from the Jurassic, this LO is inferred to coincide with the base of the Jurassic.

The LO of common Limbosporites lundbladiae is taken here as the base of the Jurassic.

\section{LO Aratrisporites}

The LO of Aratrisporites has been reported from the Sverdrup Basin (Felix 1975, Suneby and Hills 1988), with its LO at the top of the Triassic (within the Heiberg Formation). Vigran et al. (2014) also listed several species of Aratrisporites as having their LO at the top of the Triassic. Paterson and Mangerud (2015) recorded several Aratrisporites species in their uppermost samples from the Svenskøya Formation on Hopen, including Aratrisporites scabratus, Aratrisporites laevigatus, Aratrisporites macrocavatus and Aratrisporites tenuispinosus. To our knowledge, there are no records of Aratrisporites younger than Triassic in the circum- Arctic region.

The LO of Aratrisporites is taken here at the base of the Hettangian (Jurassic).

\section{LO of taeniate bisaccate pollen}

The LO of taeniate bisaccate pollen has been reported from multiple localities from the Arctic. Vigran et al. (2014) used the LO of taeniate bisaccate pollen as a top Triassic event. Suneby and Hills (1988) listed Lunatisporites rhaeticus (as Taeniasporites rhaeticus) as extending to the top of the Triassic in the Sverdrup Basin. That species was also recorded by Felix (1975) and Paterson and Mangerud (2015), the latter authors recording it as a single specimen in their 
uppermost sample from the Norian-Rhaetian Svenskøya Formation on Hopen.

The LO of taeniate bisaccate pollen is taken here at the base of the Hettangian (Jurassic).

\section{LO of Sverdrupiella mutabilis}

Sverdrupiella mutabilis has a longer stratigraphic range than other species of Sverdrupiella. Its LO is based on their occurrence in the youngest samples dated as Norian in the wells Fireweed 1 (offshore northern Alaska), Klondike OCS-Y-1482 (Chukchi Sea) and Romulus C-67 (Sverdrup Basin) in which its age assignment is constrained by Triassic miospore and Jurassic events that occur in the underying and overlying sections (Bujak et al., in press c).

The LO of Sverdrupiella mutabilis is taken here at the base of the Hettangian (Jurassic).

\section{ACKNOWLEDGEMENTS}

We are grateful to Eva Bjørseth and Bill MacMillan, who helped draft the figures, and Alina Iakovleva for help with Russian references. We would also thank the two reviewers, Sofie Lindström and Jim Riding, for valuable input. We would also like to extend our thanks to the editor, Rob Fensome for his help and suggestions; his assistance certainly goes beyond the expected. This article is a contribution to the TransGEM Event Stratigraphy activity of the Geological Survey of Canada's Geo-Mapping for Energy and Minerals Program.

\section{REFERENCES}

Balme, B.E. 1963. Plant microfossils from the Lower Triassic of Western Australia. Palaeontology, 6, pp.12-40.

Balme, B.E. 1970. Palynology of Permian and Triassic strata in the Salt Range and Surghar Range, West Pakistan. University of Kansas Department of Geology Special Publica-tion, 4, pp. 304-453.

Balme, B.E. 1980. Palynology and the Carboniferous-Permian boundary in Australia and other Gondwana continents. Palynology, 4, pp. 43-55. https://doi.org/10.1080/01916122. 1980.9989201

Bjærke, T. and Manum, S.B. 1977. Mesozoic palynology of Svalbard - I. The Rhaetian of Hopen, with a preliminary report on the Rhaetian and Jurassic of Kong Karls Land. Norsk Polarinstitutts Skrifter, 165, pp. 1-48.

Bolkhovitina, N.A. 1953. Spore and pollen characteristics of Cretaceous layers in the central regions of the USSR. Geologicheskikiy Institut, Akademiya Nauk SSSR, Trudy, Seriya Strat.I Paleontologii, Akademiya Nauk Ukrainskoi SSSR, 145 (61), pp. 3-183 (in Russian).

Bringué, M., Fensome, R.A., Poulton, T.P., Galloway, J.M., Bujak, J.P., Golding, M.L., Orchard, M.J., and Williams, G.L. In press. The 2020 Canada datapack for TimeScale
Creator: a new tool for Mesozoic-Cenozoic stratigraphy of the Canadian North. Geological Survey of Canada, Bulletin 609. https://doi.org/10.1130/abs/2020AM-353274 Brugman, W.A. 1983. Aspects of Early and Middle Triassic palynology. 1. On Dyupetalum vicentinense nov. sp. from the upper Anisian of the Southern Alps. Review of Palaeobotany and Palynology, 39, pp. 47-64. https://doi. org/10.1016/0034-6667(83)90010-6

Bugge, T., Elvebakk, G., Fanavoll, S., Mangerud, G., Smelror, M., Weiss, H.M., Gjelberg, J., Kristensen, S.E., and Nilsen, K. 2002a. Shallow stratigraphic drilling applied in hydrocarbon exploration of the Nordkapp Basin, Barents Sea. Marine and Petroleum Geology, 19, pp. 13-37. https:// doi.org/10.1016/S0264-8172(01)00051-4

Bugge, T., Ringås, J.R., Leith, D.A., Mangerud, G., Weiss, H.M., and Leith T.L. 2002b. Upper Permian as a new play model on the mid-Norwegian continental shelf: investigated by shallow stratigraphic drilling. American Association of Petroleum Geologists Bulletin, 86 (1), pp. 107-127. https://doi.org/10.1306/61EEDA4E-173E11D7-8645000102C1865D

Bujak, J.P. and Fisher, M.J. 1976. Dinoflagellate cysts from the Upper Triassic of Arctic Canada. Micropaleontology, 22, pp. 44-70. https://doi.org/10.2307/1485320

Clarke, R.F.A. 1965. Keuper miospores from Worcestershire, England. Palaeontology, 8, pp. 294-321.

Cookson, I.C. 1953. Difference in microspore composition of some samples from a bore at Comaum, South Australia. Australian Journal of Botany, 1, pp. 462-473. https:// doi.org/10.1071/BT9530462

Danzé-Corsin, J. and Laveine J.P.1963. Étude palynologique d'une argile provenance de la limite Lias-Dogger, dans un sondage à Boulogne-sur-Mer. Société géologique du Nord; Annales, 83, pp. 79-90.

de Jersey, N.J. 1959. Jurassic spores and pollen grains from the Rosewood Coalfields. Queensland Government Mining Journal, 60, pp. 346-366.

de Jersey, N.J. 1968. Triassic spores and pollen grains from the Clematis Sandstone. Geological Survey of Queensland, Publications, 338, Palaeontological Papers, no.14, pp. 1-44.

Dettmann, E. 1963. Upper Mesozoic microfloras from south-eastern Australia. Proceedings of the Royal Society of Victoria, New Series, 77, pp. 1-148.

Dolby, J.H. and Balme, B.E. 1976. Triassic palynology of the Carnarvon Basin, Western Australia. Review of Palaeobotany and Palynology, 22, pp. 105-168. https:// doi. org/10.1016/0034-6667(76)90053-1

Döring, H. 1964. Trilete Sporen aus dem oberen Jura and dem Wealden norddeutschlands. Geologie, 13 (9), pp. 1099-1129.

Elsik, W.C. 1999. Reduviasporites Wilson 1962: synonymy of the fungal organism involved in the Late Permian crisis. Palynology, 23, pp. 37-41. https://doi.org/10.1080/019161 22.1999.9989519

Embry, A.F. 1982. The Upper Triassic - Lower Jurassic Heiberg deltaic complex of the Sverdrup Basin. In Arctic geology 
and geophysics. Edited by A.F. Embry, A.F. and H. Balkwill. Canadian Society of Petroleum Geologists, Memoir 8, pp. 189-218.

Erdtman, G. 1948. Did dicotyledonous plants exist in Early Jurassic times. Grana Palynologica, 1, pp. 265-271. https://doi.org/10.1080/11035894809454085

Fefilova, L.A. 1986. The palynological reference of Triassic rocks of south part of the Barents Sea. In Theory and practice of palynological investigations of Permian and Triassic rocks in the USSR. Institut geologi Komi filiala Akademiya Nauk. SSSR. Siktivkar, pp. 131-136 (in Russian).

Fefilova, L.A. 1988. The palynological complexes of Triassic rocks of the Barents Shelf Plate. In Barents Shelf Plate. Edited by I.S. Gramberg et al. Vserossijskij NaučnoIssledo-vatel'skij Institut Geologii I Mineral'nyh Resursov Miro-vogo Okeana (VNII Okenol) Leningrad, pp. 149151 (in Russian).

Fefilova, L.A. 1990. Palynological characteristics of Triassic deposits in the southern part of the Barents Sea according to the materials from parametric drilling. In Stratigraphy and paleontology of the Mesozoic-Cenozoic of the Soviet Arctic. Edited by N.I. Shulgina. Leningrad, pp. 74-88 (in Russian).

Fefilova L.A. 2013a. Biostratigraphy, miospores and macroflora of Triassic sediments of the SE Barents Sea shelf on the example of the Krestovaya Field and adjacent areas. In Materials on the Phanerozoic biostratigraphy, fauna and flora of Russia, Atlantic Ocean and Antarctica. Edited by L.V. Nekhorosheva. Trudi NIIGA-VNIIOkeanologia, St-Petersburg, 226, pp. 42-83 (in Russian).

Fefilova L.A. 2013b. Palynological support of the lower boundary of Triassic sediments in the Admiralteyskaya-a core (Barents Sea shelf). In Materials on the Phanerozoic biostratigraphy, fauna and flora of Russia, Atlantic Ocean and Antarctica. Edited by L.V. Nekhorosheva. Trudi NIIGA-VNIIOkeanologia, St-Petersburg, 226, pp. 84-97 (in Russian).

Felix, C.J. 1975. Palynological zonation of the Heiberg Formation (Triassic-Jurassic) eastern Sverdrup Basin, Arctic Canada. Bulletin of Canadian Petroleum Geology, 36 (4), pp. 347-361.

Felix, C.J. and Burbridge, P.P. 1977. A new Ricciisporites from the Triassic of Arctic Canada. Palaeontology, 20 (3), pp. 581-587.

Felix, C.J. and Burbridge, P.P. 1978. Status of Triassic palynology in the Canadian Arctic Islands. Palinologia, Número Extraordinaire 1, pp. 225-231.

Fisher, M.J. 1979. The Triassic palynofloral succession in the Canadian Arctic Archipelago. American Association of Stratigraphic Palynologists Contribution Series, no. 5b, pp. 83-100.

Fisher, M.J. and Bujak, J.P. 1975. Upper Triassic palynofloras from Arctic Canada. Geoscience and Man,11, pp. 87-94. https://doi.org/10.1080/00721395.1975.9989758

Foster, C.B. 1979. Permian plant microfossils of the Blair Atholl Coal Measures, Baralaba Coal Measures and Basal
Rewan Formation of Queensland. Geological Survey of Queensland Publications, no. 372, pp. 1-244.

Foster, C.B., Stephenson, M.H., Marshall, C., Logan, G.A., and Greenwood, P.F. 2002. A revision of Reduviasporonites Wilson 1962: description, illustration, compari-son and biological affinities. Palynology, 26, pp. 165-183. https://doi.org/10.2113/0260035

Gilmullina, A., Klausen, T. G., Paterson, N.W., Suslova, A., and Eide, C.H. 2020. Regional correlation and seismic stratigraphy of Triassic strata in the Greater Barents Sea: implications for sediment transport in Arctic basins. Basin Research (published online 06 November 2020) https://doi.org/10.1111/bre.12526

Gradstein, F.M., Ogg, J.G., Schmitz, M.G., and Ogg, G.M. 2012. The geological time scale 2012 volume 2; pp. 681730, Elsevier, Amsterdam.

Gradstein, F.M, Ogg, J.G., Schmitz, M.D., Ogg, G.M., Agterberg, F.P., Aretz, M., Becker, T.R., Butcher, A., Ernst, R.E., Esmeray-Senlet, S., Fensome, R.A., Gale, A.S., Gréselle, B., Gibbard, P.L., Goldman, D., Grossman, E.L., Halverson, G.P., Henderson, C.M., Hesselbo, S.P., et al. 2020. The Geologic Time Scale 2020. Elsevier, Amsterdam, 2 volumes, ca. 1300 pp.

Hart, G.F. 1964. A review of the classification and distribution of the Permian miospore-Disaccate Striatiti. Cinquième Congrés International de Stratigraphie et de Geologie du Carbonifére, Compte Rendu, pp. 1171-1199.

Hermann, E., Hochuli P.A., Bucher, H., Vigran, J.O., Weissert, H., and Bernasconi, S.M. 2010. A close-up view of the Permian-Triassic boundary based on expanded organic carbon isotope records from Norway (Trøndelag Platform and Finnmark Platform). Global and Planetary Change, 74, pp. 156-162. https://doi.org/10.1016/j.gloplacha.2010.10.007

Hochuli, P.A. 2016. Interpretation of "fungal spikes" in Permian-Triassic boundary sections. Global and Planetary Change, Short Communication, 144, pp. 45-50. https://doi.org/10.1016/j.gloplacha.2016.05.002

Hochuli, P.A. and Vigran, J.O. 2010. Climate variations in the Boreal Triassic - inferred from palynological records in the Barents Sea. Palaeogeography, Palaeoclimatology, Palaeoecology 290, pp. 20-42. https://doi.org/10.1016/j. palaeo.2009.08.013

Hochuli, P.A., Colin, J.P., and Vigran, J.O. 1989. Triassic biostratigraphy of the Barents Sea area. In Correlation in hydrocarbon exploration. Edited by J. Collinson. Graham and Trotman, London, pp. 131-153. https://doi. org/10.1007/978-94-009-1149-9_12

Hochuli, P.A., Vigran, J.O., Hermann, E., and Bucher, H. 2009. Multiple climatic changes around the PermianTriassic boundary event revealed by an expanded palynological record from mid-Norway. Geological Society of America Bulletin, 122 (5-6), pp. 884-896. https://doi. org/10.1130/B26551.1

Hochuli, P.A., Hermann, E., Vigran, J. O., Bucher, H., and Weissert, H. 2010. Rapid demise and recovery of plant ecosystems across the end-Permian extinction event. 
Global and Planetary Change, 74, pp. 144-155. https:// doi.org/10.1016/j.gloplacha.2010.10.004

Hochuli, P.A., Hermann, E., Mangerud, G., and Bucher, H. 2017. Evidence for atmospheric pollution across the Permian-Triassic transition. Geology 45 (12), pp. 11231126. https://doi.org/10.1130/G39496.1

Hounslow, M.W., Yu, M., Mørk, A., Weitschat, W., Vigran, J.O., Karloukovski, V., and Orchard, M.J. 2008. Intercalibration of Boreal and Tethyan time scales: the magnetobiostratigraphy of the Middle Triassic and the latest Early Triassic from Spitsbergen, Arctic Norway. Polar Research, 27 (3), pp. 469-490. https://doi.org/10.1111/j.1751$\underline{8369.2008 .00074 . \mathrm{x}}$

Ilyina, N.W. and Egorov, A.Y. 2008. The Upper Triassic of northern Middle Siberia: stratigraphy and palynology. Polar Research, 27, pp. 372-392. https://doi.org/10.1111/ j.1751-8369.2008.00083.x

Jansonius, J. 1962. Palynology of Permian and Triassic sediments, Peace River area, western Canada. Palaeontographica Abteilung B, 110 (1-4), pp. 35-98.

Jansonius, J. and Hills, L.V. 1979. Genera File of fossil spores. Special Publication, Department of Geology and Geophysics, University of Calgary, Supplement 3, cards 3521-3628.

Kar, R.K., Kieser G., and Jain, K.P. 1972. Permo-Triassic subsurface palynology from Libya. Pollen et Spores, 14 (4), pp. 389-453.

Klaus, W. 1955. Über die Sporendiagnose des deutschen Zechsteinsalzes und des alpinen Salzgebirges. Zeitschriften der Deutschen Geologischen Gesellschaft, 105 (4), pp. 776-788 (volume dated 1953, published in 1955).

Klaus, W. 1960. Sporen der karnischen Stufe der Ostalpinen Trias. Jahrbuch der Geologischen Bundesanstalt Sonderbände, 5, pp.107-184.

Klaus, W. 1964. Zur sporenstratigraphischen Einstufung von gipsfuehrenden Schichten in Bohrungen. Erdöl Erdoel-Zeitschrift, 4, pp. 119-132.

Krutzsch, W. 1963. Atlas der mittel- und jungtertiären dispersen Sporen- und Pollen sowie der Mikroplanktonformen des nördlichen Mitteleuropas 2. Die Sporen der Anthocerotaceae und der Lycopodiaceae. Abhandlungen des Zentralen Geologischen Instituts, 2, p. 1-141.

Leschik, G. 1955. Die Keuperflora von Neuewelt bei Basel. II. Die Iso-und Mikrosporen. Schweizerische Paläontologische Abhandlungen, 72, pp. 5-70.

Leschik, G. 1956. Die Keuperflora yon Neuwelt bei Basel. II. Die Iso- und Mikrosporen. Schweizerische Paläontologische Abhandlungen, 71, pp. 1-70.

Lindström, S. 2016. Palynofloral pattern of terrestrial ecosystem change during the end-Triassic event - a review. Geological Magazine, 153 (2), pp. 223-251. https://doi. org/10.1017/S0016756815000552

Lindström, S., Bjerager, M., Alsen, P., Sanei, H. and Bojesen-Koefoed, J. 2020. The Smithian-Spathian boundary in North Greenland: implications for extreme global climate changes. Geological Magazine. https://doi. org $/ 10.1017 /$ S0016756819000669

Loeblich, A.R. Jr. and Loeblich, A.R. III. 1968. Index to the genera, subgenera, and sections of the Pyrrhophyta, II. Journal of Paleontology, 42, pp. 210-213.

Looy, C.V., Twitchett, R.J., Dilcher, D.L., van Konijnenburg-van Cittert, J.H.A, and Visscher, H. 2001. Life in the end-Permian dead zone. Proceedings of the National Academy of Sciences of the USA., 98 (14), pp. 7879-7883. https://doi.org/10.1073/pnas.131218098

Lord, G.S., Solvi, K.H., Ask, M., Mørk, A., Hounslow, M.W., and Paterson, N.W. 2014. The Hopen Member: a new lithostratigraphic unit on Hopen and equivalent to the Isfjorden Member of Spitsbergen. Norwegian Petroleum Directorate Bulletin, no. 11, pp. 81-96.

Lundblad, B. 1954. Contributions to the geological history of the Hepaticae; fossil Marchantiales from the RhaeticLiassic coal-mines of Skromberga (prov. of Scania); Sweden. Svensk Botanisk Tidskrift, 48 (2), pp. 381-416.

Mädler, K. 1964. Bemerkenswerte Sporenformen aus dem Keuper und unteren Lias. Fortschritte in der Geologie von Rheinland und Westfalen, 12, pp.169-200.

Malyavkina, V.S. 1949. Determination key of spores and pollen, Jurassic-Cretaceous; Trudy Vsesoyuznogo Neftyanogo Naucho-Issledovatel Skogo Geologo-Razvedochnogo Instituta, Trudy, (VNIGRI), 33, pp. 1-137 (in Russian).

Mander, L. 2011. Taxonomic resolution of the Triassic-Jurassic sporomorph record in East Greenland. Journal of Micropalaeontology, 30, pp. 107-118. https://doi. org/10.1144/0262-821X11-012

Mander, L., Kürschner, W.M., and McElwain, J.C. 2010. An explanation for conflicting records of Triassic-Jurassic plant diversity. Proceedings of the National Academy of Sciences of the USA, 107, pp. 15351-15356. https://doi. org/10.1073/pnas.1004207107

Mander, L., Kürschner, W.M., and McElwain, J.C. 2013. Palyoostratigraphy and vegetation history of the TriassicJurassic transition in East Greenland. Journal of the Geo-logical Society of London, 170, p. 37-46.

Mangerud, G. 1994. Palynostratigraphy of the Permian and lowermost Triassic succession, Finnmark Platform, Barents Sea. Review of Palaeobotany and Palynology, 82, pp. 317-349. https://doi.org/10.1144/jgs2012-018

Mangerud, G. and Konieczny, R. 1993. Palynology of the Permian succession of Spitsbergen. Svalbard; Polar Research, 12 (1), p. 65-93. https://doi.org/10.3402/polar. v12i1.6704

Mangerud, G. and Rømuld, A. 1991. Spathian-Anisian (Triassic) palynology at the Svalis Dome, southwestern Barents Sea. Review of Palaeobotany and Palynology, 70, pp. 199-216. https://doi.org/10.1016/0034-6667(91)90002-K

Mangerud, G., Paterson, N.W., and Riding, J.B. 2018. The temporal and spatial distribution of Triassic dinoflagellate cysts. Review of Palaeobotany and Palynology, 261, pp. 53-66. https://doi.org/10.1016/j.revpalbo.2018.11.010

Morbey, S.J. 1975. The palynostratigraphy of the Rhaetian stage, Upper Triassic in the Kendelbachgraben, Austria. Palaeontographica Abteilung B, 152, pp. 1-75. 
Mørk, A., Vigran, J.O., and Hochuli, P.A. 1990. Geology and palynology of the Triassic succession of Bjørnøya. Polar Research, 8, pp. 141-163. https://doi.org/10.3402/polar. $\mathrm{v} 8 \mathrm{i} 2.6810$

Mørk, A., Vigran, J.O., Korchinskaya, M.V., Pchelina, T.M., Fefilova, L.A., Vavilov, M.N., and Weitschat, W. 1993. Triassic rocks in Svalbard, the Arctic Soviet islands and the Barents Shelf: bearing on their correlations. In Arctic Geology and Petroleum Potential. Edited by T.O. Vorren, E. Bergsager, Ø.A. Dahl-Stamnes, E. Holter, B. Johansen, E. Lie and T.B. Lund. Norwegian Petroleum Society Special Publication no. 2 Elsevier, Amsterdam, pp. 457479. https://doi.org/10.1016/B978-0-444-88943-0.50033-2

Mørk, A., Elvebakk, G., Forsberg, A.W., Hounslow, M.W., Nakrem, H.A., Vigran, J.O., and Weitschat, W. 1999. The type section of Vikinghøgda Formation: a new Lower Triassic unit in central and eastern Svalbard. Polar Research, 18, pp. 51-82. https://doi.org/10.3402/polar.v18i1.6558

Mueller, S., Veld, H., Nagy, J., and Kürschner, W.M. 2014. Depositional history of the Upper Triassic Kapp Toscana Group on Svalbard, Norway, inferred from palynofacies analysis and organic geochemistry. Sedimentary Geology, 310, pp. 16-29. https://doi.org/ 10.1016/j.sed-geo.2014.06.003

Mueller, S., Hounslow M.W., and Kürschner W.M. 2016. Integrated stratigraphy and palaeoclimate history of the Carnian Pluvial Event in the Boreal Realm; new data from the Upper Triassic Kapp Toscana Group in central Spitsbergen (Norway). Journal of the Geological Society, 173, pp. 186-202. https://doi.org/10.1144/igs2015-028

Nagy, J., Hess, S., Dypvik, H., and Bjærke, T. 2011. Marine shelf to paralic biofacies of Upper Triassic to Lower Jurassic deposits in Spitsbergen. Palaeogeography, Palaeo-climatology, Palaeoecology, 300, pp. 138-151. https://doi. org/10.1016/j.palaeo.2010.12.018

Nilsson, T. 1958. Uber das Vorkommen eines mesozoischen Sapropelgesteins in Schonen; Lunds Universitets Arsskrift, Ny Följd, Avd. 2, 54 (10), pp.1-112.

Norford, B.S., Brideaux, W.W., Chamney, T.P., Copeland, M.J., Frebold, H., Hopkins, W.S., Jr., Jeletzky J.A., Johnson, B., McGregor, D.C., Norris, S.W., Pedder, A.E.H., Tozer, E.T., and Uyeno, T.T. 1973. Biostratigraphic determinations of fossils from the subsurface of the Yukon Territory and the districts of Franklin, Keewatin and Mack-enzie. Geological Survey of Canada, Paper 72-38, pp 29. https://doi.org/10.4095/102267

Pant, D.B. and Srivastava, G.K. 1964. Further observations on some Triassic plant remains from the Salt Range, Punjab. Palaeontographica Abteilung B, 114, pp. 79-93.

Paterson, N.W. and Mangerud G. 2015. Late Triassic (Carnian-Rhaetian) palynology of Hopen, Svalbard. Review of Palaeobotany and Palynology, 220, pp. 98-119. https://doi.org/10.1016/j.revpalbo.2015.05.001

Paterson N.W. and Mangerud G. 2017. Palynology and depositional environments of the Middle to Late Triassic age (Anisian-Rhaetian) Kobbe, Snadd and Fruholmen formations, southern Barents Sea, Arctic Norway. Marine and Petroleum Geology, 86, pp. 304-324. https://doi. org/10.1016/j.marpetgeo.2017.05.033

Paterson N.W. and Mangerud G. 2019. A revised palynozonation for the Middle-Upper Triassic (Anisian-Rhaetian) series of the Norwegian Arctic. Geological Magazine 157 (19), pp. 1562-1592. https://doi-org.pva.uib.no/10.1017/ $\underline{\text { S0016756819000906 }}$

Paterson, N.W., Mangerud, G., Cetean, C.G., Mørk, A., Lord, S.G., Klausen, T.G., and Mørkved, P.T. 2016. A multidisciplinary biofacies characterisation of the Late Triassic (late Carnian - Rhaetian) Kapp Toscana Group on Hopen, Arctic Norway. Palaeogeography, Palaeoclimatology, Palaeoecology, 464, pp. 16-72. https:// doi.org/10.1016/j.pa-laeo.2015.10.035

Paterson N.W., Mangerud G., and Mørk A. 2017. Late Triassic (early Carnian) palynostratigraphy of shallow stratigraphic core 7830/5-U-1, offshore Kong Karls Land, Norwegian Arctic. Palynology, 41, pp. 230-254. https://doi.or g/10.1080/01916122.2016.1163295

Paterson N.W., Mangerud G., Holen L.H., Landa J., Lundschien B.A., and Eide, F. 2018. Late Triassic (early Carnian - Norian) palynology of four stratigraphical cores from the Sentralbanken High, Barents Sea, Arctic Norway. Palynology, 43 (1); 53-75 (published online with provisional pagination in 2018, paginated version published in 2019). https://doi.org/10.1080/01916122.2017.1413018

Pavlov, V.V., Fefilova, L.A., and Lodkina, L.B. 1985. Palynological characterization of the Mesozoic deposits of the southern Barents Sea Shelf. In Stratigrafiya I paleontologiya Mesozoyskikh osadochnykh basseynov severa SSSR. Edited by N.D. Vasilevskaya. PGO Sevmorgeologiya Vserossijskij Naučno-Issledovatel'skij Institut Geologii I Mineral'nyh Resursov Mirovogo Okeana (VNIIOkeanologiya), Leningrad, pp. 88-103.

Pedersen, K.R. and Lund, J.J. 1980. Palynology of the plant-bearing Rhaetian to Hettangian Kap Stewart Formation, Scoresby Sund, East Greenland. Review of Palaeobotany and Palynology, 31, pp. 1-69. https://doi. org/10.1016/0034-6667(80)90022-6

Piasecki, S. 1984. Preliminary palynostratigraphy of the Permian - Lower Triassic sediments in Jameson Land and Scoresby Land, East Greenland. Bulletin of the Geological Society of Denmark, 32, pp.139-144.

Playford, G. 1965. Plant microfossils from Triassic sediments near Poatina, Tasmania. Journal of the Geological Society of Australia, 12, pp. 173-210. https://doi. org/10.1080/00167616508728592

Playford, G. and Dettmann, M.E. 1965. Rhaeto-Liassic plant microfossils from Leigh Creek Coal Measures, South Australia. Senckenberg; Lethaea, 46, pp. 127-181.

Potonié R. 1958. Synopsis der Gattungen der Sporae dispersae. II. Teil: Sporites (Nachträge), Saccites, Aletes, Praecolpates, Polyplicates, Monocolpates. Geologisches Jahrbuch, Beihefte, no.31, pp. 1-113.

Reinhardt, P. 1961. Sporae dispersae of the Rhaetian of Thuringen. Monatsberichte der Deutschen Akademie der Wisssenschaften (Berlin), 3 (1112), pp. 704-711. 
Reissinger, A. 1950. Die "Pollenanalyse", ausgedehnt auf alle Sedimentgesteine der geologischen Vergangenheit II. Paleontographica Abteilung B, 90, pp. 99-126.

Rise, L. and Sættem, J. 1994. Shallow stratigraphic wireline coring in bedrock offshore Norway. Scientific Drilling, 4, pp. 243-257.

Rossi, V.M., Paterson, N.W., Helland-Hansen, W., Klausen, T.G., and Eide, C.H. 2019. Mud-rich delta-scale compound clinoforms in the Triassic shelf of northern Pangea (Havert Formation, south-western Barents Sea). Sedimentology 66, 2234-2267. https://doi.org/10.1111/ sed. 12598

Samoilovich S.R. 1953. Pollen and spores from the Permian deposits of the Cherdya and Aktyubinsk areas, Cis-Urals. Oklahoma Geological Survey Circular, 56, pp. 1-103.

Sarjeant, W.A.S. 1963. Fossil dinoflagellates from Upper Triassic sediments. Nature, 199, pp. 353-354. https://doi. org/10.1038/199353a0

Sarjeant, W.A.S. 1966. Dinoflagellate cysts with Gonyaulaxtype tabulation. In Studies on Mesozoic and Cainozoic dinoflagellate cysts. Edited by R.J. Davey, C. Downie, W.A.S. Sarjeant and G.L. Williams. British Museum (Natural History) Geology, Bulletin, Supplement 3, pp.107-156.

Scheuring, B.W. 1970. Palynologische und palynostratigrafische Untersuchungen des Keupers im Bolchentunnel (Solothurner Jura). Schweizerische Paläontologische Abhandlungen, 88, pp. 1-119.

Scheuring, B.W. 1978. Mikrofloren aus den Meridekalken des Mte. San Giorgio (Kanton Tessin). Schweizerische Palaeontologische Abhandlungen, 100, pp. 1-205.

Schneebeli-Hermann, E., Hochuli, P.A., and Bucher, H. 2017. Palynofloral associations before and after the Permian-Triassic mass extinction, Kap Stosch, East Greenland. Global and Planetary Change, 155, pp. 178-195. https:// doi.org/10.1016/j.gloplacha.2017.06.009

Schulz, E. 1964. Sporen und pollen aus dem mittleren Buntsandstein des germanischen Beckens. Monatsberichte der Deutschen Akademie der Wissenschaften zu Berlin, 6 (8), pp. 597-606.

Schulz, E. 1966. Über einige Sporae Dispersae aus dem älteren Mesophyticum Deutschlands. Geologie, 15, pp.130-151.

Schulz E. 1967. Sporenpaläontologische Untersuchungen räto-liassischer Schichten im Zentralteil des Germanischen Beckens. (Palynological investigations of the Rhaetian-Liassic Layers in the central part of the Germanic Basin.) Paläontologische Abhandlungen, Abteilung B, 2, pp. 427-633.

Schulz, E. and Krutzsch, W. 1961. Echinitosporites iliacoides nov. fgen. et fsp. Eine, neue Sporenform aus dem Keuper der Niederlausitz. Geologie, 10, pp. 122-127.

Schuurman, W.M.L. 1976. Aspects of Late Triassic palynology. 1. On the morphology, taxonomy and stratigraphical/ geographical distribution of the form genus Ovalipollis. Review of Palaeobotany and Palynology, 21, pp. 241-266. https://doi.org/10.1016/0034-6667(76)90042-7
Singh, H.P. 1964. A miospore assemblage from the Permian of Iraq. Palaeontology, 7 (2), pp. 240-265.

Smith, D.G., Harland, W.B., and Hughes, N.F. 1975. Geology of Hopen, Svalbard. Geological Magazine, 112 (1), pp. 1-23. https://doi.org/10.1017/S0016756800045544

Sømme, T.O., Doré, A.G., Lundin, E.R., and Tørudbakken, B.O. 2018. Triassic-Paleogene paleogeography of the Arctic: implications for sediment routing and basin fill. American Association of Petroleum Geologists Bulletin, 102,pp. 2481-2517. https://doi.org/10.1306/05111817254

Stover, L.E. and Evitt, W.R. 1978. Analyses of pre-Pleistocene organic-walled dinoflagellates. Stanford University Publications, Geological Sciences, no. 15, 300 pp.

Suneby L.B. and Hills L.V. 1988. Palynological zonation of the Heiberg Formation (Triassic-Jurassic) eastern Sverdrup Basin, Arctic Canada. Bulletin of Canadian Petro-leum Geology, 36 (4), pp. 347-361.

Thiergart, F. 1949. Der Stratigraphische Wert mesozoischer Pollen und Sporen; Palaeontographica, Abteilung B, 89, pp. 1-34.

Tozer, E.T. 1967. A standard for Triassic time. Geological Survey of Canada, Bulletin, 156, 103 pp. https://doi.org/ $\underline{10.4095 / 101452}$

Turland, N.J., Wiersema, J.H., Barrie, F.R., Greuter, W., Hawksworth, D.L., Herendeen, P.S., Knapp, S., Kusber, W.-H., Li Dezhu, Marhold, K., May, T.W., McNeill, J., Monro, A.M., Prado, J., Price, M.J. and Smith, G.F. 2018. International Code of Nomenclature for algae, fungi, and plants (Shenzhen Code) adopted by the Nineteenth International Botanical Congress Shenzhen, China, July 2017. https://doi.org/10.12705/Code.2018

Twitchett, R.J., Looy, C.V., Morante, R., Visscher, H., and Wignall, P.B. 2001. Rapid and synchronous collapse of marine and terrestrial ecosystems during the end-Permian biotic crisis. Geology, 29 (4), pp. 351-354. https://doi. org/10.1130/0091-7613(2001)029<0351:RASCOM $>2.0$.

\section{$\mathrm{CO} ; 2$}

Utting, J. 1985. Preliminary results of palynological studies of the Permian and lowermost Triassic sediments, Sabine Peninsula, Melville Island, Canadian Arctic Archipelago. In Current research, part B; Geological Survey of Canada Paper 85-1B, pp. 231-238 https://doi.org/10.4095/120249

Utting, J. 1989. Preliminary palynological zonation of surface and subsurface sections of Carboniferous, Permian and lowest Triassic rocks, Sverdrup Basin, Canadian Arctic Archipelago. In Current research part G, Frontier Geoscience Program, Arctic Canada; Geological Survey of Canada Paper 89-1G, pp. 233-240. https://doi. org/10.4095/127606

Utting, J. 1994. Palynostratigraphy of Permian and Lower Triassic rocks, Sverdrup Basin. Canadian Arctic Archipelago. Geological Survey of Canada Bulletin 478, pp. 1-107. https://doi.org/10.4095/194811

Utting, J., Spina, A., Jansonius, J., Mc Gregor, C.D., and Marshall, J.E.A. 2004. Reworked miospores in Upper Paleozoic and Lower Triassic of the northern circum-polar area and selected localities. Palynology, 28, pp. 75-119. 
https://doi.org/10.2113/28.1.75

van Veen, P.M. 1985. Stratigraphy of the Triassic in the Troms Area. Rapport, Oljedirektoratet, OD-85-36, pp. $1-125$.

Vigran J.O., Mangerud G., Mørk A., Bugge, T., and Weitschat, W. 1998. Biostratigraphy and sequence stratigraphy of the Lower and Middle Triassic deposits from the Svalis Dome, central Barents Sea. Palynology, 22, pp. 89-141. https://doi.org/10.1080/01916122.1998.9989505

Vigran, J.O., Mangerud G., Mørk A., Worsley D., and Hochuli P.A. 2014. Palynology and geology of the Triassic succession of Svalbard and the Barents Sea. Geological Survey of Norway Special Publication 14, pp. 1-247.

Warrington, G. 1974. Studies in the palynological biostratigraphy of the British Trias. 1. reference sections in West Lancashire and North Someret. Review of Palaeobotany and Palynology, 17, pp. 133-147. https://doi. org/10.1016/0034-6667(74)90095-5

Wiggins, V.D. 1973. Upper Triassic dinoflagellates from arctic Alaska. Micropaleontology, 19 (1), pp. 1-17. https://doi. org/10.2307/1484961

Wilson, L.R. 1962. Permian plant microfossils from the Flowerpot Formation. Oklahoma. Geological Survey Circular 49, pp. 1-24.

Wodehouse, R.P. 1933. Tertiary pollen II. The oil shales of the Eocene Green River Formation. Bulletin of the
Torrey Botanical Club, 60, pp. 479-524. https://doi. org/10.2307/2480586

Xu, G., Hannah, J.L., Stein, H.J., Bingen, B., Yang, G., Zimmermann, A., Weitschat, W., Mork, A., and Weiss, H.M. 2009. Re-Os geochronology of Arctic black shales to evaluate the Anisian-Ladinian boundary and global fauna correlations. Earth and Planetary Science Letters, 288, pp. 581-587. https://doi.org/10.1016/j.epsl.2009.10.022

Xu, G., Hannah, J.L., Stein, H.J., Mørk, A., Vigran, J.O., Bingen, B., Schutt, D.L., and Lundschien, B.A. 2014. Cause of Upper Triassic climate crisis revealed by Re-Os geo-chemistry of Boreal black shales. Palaeogeography, Palae-oclimatology, Palaeoecology, 395, pp. 222-232. https://doi.org/10.1016/j.palaeo.2013.12.027

Yaroshenko, O.P., and Golubeva, L.P. 1989. New species of Lower Triassic spores from the Pechora Syneclise. Paleontological Journal, Akademiya Nauk SSSR, 4, pp. 101108 (in Russian).

Yaroshenko, O.P, Golubeva, L.P., and Kalantar, I.Z.1991. Miospores and Lower Triassic stratigraphy of the Pechora Syneclise. Ordena Trudovogo Krasnogo Znameni, Geologicheskii Instityt, Akademiya Nauk SSSR, 470, pp. 1-134 (in Russian).

Editorial responsibility: Robert A. Fensome

Appendices on following pages 


\section{Miospores}

Anapiculatisporites spiniger Leschik 1955 (now Carnisporites spiniger)

Aratrisporites Leschik 1956

Aratrisporites coryliseminis Klaus 1960

Aratrisporites laevigatus Bjærke and Manum 1977

Aratrisporites macrocavatus Bjærke and Manum 1977

Aratrisporites scabratus Klaus 1960

Aratrisporites tenuispinosus Playford 1965

Aulisporites astigmosus (Leschik 1955) Klaus 1960

Camarozonosporites laevigatus Schulz 1967

Camarozonosporites rudis (Leschik 1955) Klaus 1960

Camerosporites secatus (Leschik 1956) Scheuring 1978

Carnisporites spiniger (Leschik 1955) Morbey 1975

Chasmatosporites Nilsson 1958

Chasmatosporites magnolioides (Erdtman 1948) Nilsson 1958

Concavisporites crassexinus Nilsson 1958

Classopollis torosus (Reissinger 1950) Klaus 1960

Cordaitina gunyalensis (Pant and Srivastava 1964) Balme 1970

Cycadopites Wodehouse 1933

Cyclotriletes Mädler 1964

Cyclotriletes oligogranifer Mädler 1964

Cyclotriletes pustulatus Mädler 1964

Densoisporites nejburgii (Schulz 1964) Balme 1970

Dictyophyllidites mortonii (de Jersey 1959) Playford and Dettmann 1965

Dyupetalum Jansonius and Hills 1979

Dyupetalum vicentinense Brugman 1983

Echinitosporites iliacoides Schulz and Krutzsch 1961

Enzonalasporites vigens Leschik 1955

Ephedripites steevesii (Jansonius 1962) de Jersey 1968

Illinites chitonoides Klaus 1964

Iraqispora labrata Singh 1964

Jerseyiaspora punctispinosa Kar et al. 1972

Kraeuselisporites cooksoniae (Klaus 1960) Dettmann 1963

Kyrtomisporis Mädler 1964

Kyrtomisporis gracilis Mädler 1964

Kyrtomisporis laevigatus Mädler 1964

Kyrtomisporis moerki Paterson and Mangerud 2019

Kyrtomisporis speciosus Mädler 1964

Kyrtomisporis sp. A of Paterson et al. (2017) (now Kyrtomisporis moerki)

Lunatisporites noviaulensis (Leschik 1956) Scheuring 1970

Lunatisporites rhaeticus (Schulz 1967) Warrington 1974

Leschikisporis aduncus (Leschik 1955) Potonié 1958

Limbosporites lundbladiae Nilsson 1958 (epithet commonly cited as lundbladii, but since nominal individual was female the corrected epithet is used herein; Turland et al . 2018, Article 60.8b).

Naumovaspora striata Jansonius 1962

Ovalipollis pseudoalatus (Thiergart 1949) Schuurman 1976

Pechorosporites disertus Yaroshenko and Golubeva 1989

Podosporites vigraniae Paterson and Mangerud 2019

Polycingulatisporites crenulatus Playford and Dettmann 1965

Porcellispora longdonensis (Clarke 1965) Morbey 1975

Pretricolpipollenites Danzé-Corsin and Laveine 1963 
APPENDIX A: Continued.

Proprisporites pocockii Jansonius 1962

Protodiploxypinus Samoilovich 1953

Protodiploxypinus decus Scheuring 1970

Protodiploxypinus ornatus Scheuring 1970

Punctatisporites fungosus Balme 1963

Retitriletes austroclavatidites (Cookson 1953) Döring, Krutzsch, Mai and Schulz in Krutzsch 1963

Quadraeculina anellaeformis Malyavkina 1949

Ricciisporites tuberculatus Lundblad 1954

Ricciisporites umbonatus Felix and Burbridge 1977

Schizaeoisporites worsleyi Bjærke and Manum 1977

Semiretisporis "barentszi" of van Veen (1985) and Vigran et al. (2014) (name not validly published; now Semiretisporis hochulii)

Semiretisporis sp. A of Vigran et al. (1998) (now Semiretisporis hochulii)

Semiretisporis sp. 1 of Hounslow et al. 2008 (now Semiretisporis hochulii)

Semiretisporis hochulii Paterson and Mangerud 2019

Staurosaccites quadrificus Dolby in Dolby and Balme 1976

Striatella seebergensis Mädler 1964

Striatoabieites richteri (Klaus 1955) Hart 1964

Taeniasporites rhaeticus (Schulz 1967) Warrington 1974

Triadispora obscura Scheuring 1970

Triadispora verrucata (Schulz 1966) Scheuring 1970

Triancoraesporites ancorae (Reinhardt 1961) Schulz 1967

Uvaesporites argentaeformis (Bolkhovitina 1953) Schulz 1967

Uvaesporites imperialis (Jansonius 1962) Utting 1994

Vittatina Samoilovich 1953 ex Wilson 1962

\section{Dinoflagellates}

Hebecysta brevicornuta Bujak and Fisher 1976

Heibergella Bujak and Fisher 1976

Heibergella asymmetrica Bujak and Fisher 1976

Heibergella salebrosacea Bujak and Fisher 1976

Noricysta Bujak and Fisher 1976

Noricysta fimbriata Bujak and Fisher 1976

Noricysta pannucea Bujak and Fisher 1976

Noricysta varivallata Bujak and Fisher 1976

Rhaetogonyaulax Sarjeant 1966

Rhaetogonyaulax arctica (Wiggins 1973) Stover and Evitt 1978

Rhaetogonyaulax rhaetica (Sarjeant 1963) Loeblich Jr. and Loeblich III 1968

Sverdrupiella Bujak and Fisher 1976

Sverdrupiella baccata Bujak and Fisher 1976

Sverdrupiella manicata Bujak and Fisher 1976

Sverdrupiella mutabilis Bujak and Fisher 1976

Sverdrupiella ornaticingulata Bujak and Fisher 1976

Sverdrupiella raiaformis Bujak and Fisher 1976

Sverdrupiella sabinensis Bujak and Fisher 1976

Sverdrupiella septentrionalis Bujak and Fisher 1976

Sverdrupiella spinosa Bujak and Fisher 1976

Sverdrupiella usitata Bujak and Fisher 1976

Other groups

Maculatasporites Döring 1964

Reduviasporonites chalastus (Foster 1979) Elsik 1999

Tympanicysta stoschiana Balme 1980 (considered a taxonomic junior synonym of Reduviasporonites chalastus) 


\begin{tabular}{|c|c|}
\hline Event & Summary of TsC link \\
\hline FO of common Uvaesporites imperialis & base of the Otoceras concavum ammonoid zone \\
\hline FO of Reduviasporonites chalastus & base of the Otoceras concavum ammonoid zone \\
\hline FO of Lunatisporites noviaulensis & base of the Griesbachian \\
\hline FO of Ephedripites steevesii & base of the Griesbachian \\
\hline LO of common Uvaesporites imperialis & $5 \%$ above the base of the Griesbachian \\
\hline FO of consistent Proprisporites pocockii & base of the Ophiceras commune ammonoid zone \\
\hline FO of consistent Aratrisporites & base of the ammonoid Ophiceras commune Zone \\
\hline LO of Vittatina & $70 \%$ up from base Griesbachian \\
\hline FO of common Densoisporites nejburgii & base of the Boreal ammonoid Vavilovites sverdrupi Zone \\
\hline FO of consistent Maculatasporites & base of the Boreal ammonoid Vavilovites sverdrupi Zone \\
\hline LOs of common Cycadopites and Pretricolpipollenites & base of the Smithian \\
\hline FO of common/abundant Punctatisporites fungosus & base of the Boreal ammonoid Euflemingites romunderi Zone \\
\hline LO of sporadic Proprisporites pocockii & $50 \%$ up from the base of the ammonoid Wasatchites tardus Zone \\
\hline LO of sporadic Naumovaspora striata & base of the Spathian \\
\hline LO of common Punctatisporites fungosus & base of the Spathian \\
\hline FO of common Pechorosporites disertus & base of the Spathian \\
\hline LO of common Pechorosporites disertus & base of the ammonoid Keyserlingites subrobustus Zone \\
\hline FO of Jerseyiaspora punctispinosa & base of the late Spathian Boreal ammonoid Keyserlingites subrobustus \\
\hline FO of Protodiploxypinus & base of the Boreal ammonoid Keyserlingites subrobustus Zone \\
\hline FO of Cyclotriletes oligogranifer & base of the Boreal ammonoid Keyserlingites subrobustus Zone \\
\hline FO of sporadic Striatella seebergensis & base of the Boreal ammonoid Keyserlingites subrobustus Zone \\
\hline FO of consistent Carnisporites spiniger & base of the Boreal ammonoid Karangatites evolutus Zone \\
\hline FO of consistent Illinites chitonoides & base of the Boreal ammonoid Karangatites evolutus Zone \\
\hline FO of consistent Cordaitina gunyalensis & base of the Anisian \\
\hline FO of consistent Dyupetalum vicentinense & base of the middle Anisian Boreal ammonoid Anagymnotoceras varium \\
\hline LO of consistent Densoisporites nejburgii & $50 \%$ from the base of the ammonoid Anagymnotoceras varium Zone \\
\hline LO of consistent Jerseyiaspora punctispinosa & $50 \%$ up from the base Anisian \\
\hline FO of consistent/common Chasmatosporites & base of the late Anisian ammonoid Frechites laqueatus Zone \\
\hline FO Protodiploxypinus decus & base of the ammonoid Frechites laqueatus Zone \\
\hline FO of consistent Protodiploxypinus ornatus & base of the ammonoid Frechites laqueatus Zone \\
\hline FO of Echinitosporites iliacoides & base of the Ladinian \\
\hline FO of consistent Schizaeoisporites worsleyi & base of the Ladinian \\
\hline FO of consistent Triadispora verrucata & base of the Ladinian \\
\hline FO of Ovalipollis pseudoalatus & base of the Ladinian \\
\hline FO of consistent Staurosaccites quadrifidus & base of the Ladinian \\
\hline FO of common to abundant Semiretisporis hochulii & base of the Ladinian \\
\hline FO of sporadic Enzonalasporites vigens & base of the Carnian \\
\hline FO of sporadic Camerosporites secatus & base of the Carnian \\
\hline FO of consistent Aulisporites astigmosus & base of the Carnian \\
\hline LO of sporadic Cordaitina gunyalensis & $10 \%$ up from the base of the Carnian \\
\hline LO of Echinitosporites iliacoides & $10 \%$ up from the base of the Carnian \\
\hline LO of common Semiretisporis hochulii & $10 \%$ up from the base of the Carnian \\
\hline FO of common Podosporites vigraniae & $10 \%$ up from the base of the Carnian \\
\hline FO of sporadic Ricciisporites tuberculatus & $10 \%$ up from the base of the Carnian \\
\hline FO of consistent Camarozonosporites rudis & $10 \%$ up from the base of the Carnian \\
\hline FO of rare Uvaesporites argentaeformis & $10 \%$ up from the base of the Carnian \\
\hline FO of Kyrtomisporis moerki & $10 \%$ up from the base of the Carnian \\
\hline LO of Kyrtomisporis moerki & base of the Tuvalian (upper Carnian) \\
\hline FO of consistent Kyrtomisporis spp & base of the Tuvalian (upper Carnian) \\
\hline LO of Dyupetalum vicentinense & base of the Tuvalian (upper Carnian) \\
\hline FO of dominant Leschikisporis aduncus & base of the Tuvalian (upper Carnian) \\
\hline FO of abundant Protodiploxypinus & base of the Tuvalian (upper Carnian) \\
\hline LO of dominant Leschikisporis aduncus & base of the Tuvalian (upper Carnian) \\
\hline
\end{tabular}


APPENDIX B: Continued.

FO of rare Rhaetogonyaulax

LO of consistent Schizaeoisporites worsleyi

LO of sporadic Aulisporites astigmosus

LO of abundant Protodiploxypinus

LO of consistent Illinites chitonoides

FO of common Rhaetogonyaulax

FOs of Hebecysta, Heibergella, Noricysta and

FO of Classopollis torosus

FO sporadic Limbosporites lundbladiae

FO of sporadic Quadraeculina anellaeformis

FO of consistent Riccisporites tuberculatus

LO of Kraeuselisporites cooksonae

LO of Porcellispora longdonensis

FO of consistent Limbosporites lundbladiae

FO of consistent Quadraeculina anellaeformis

FO of common Riccisporites tuberculatus

FO of Polycingulatisporites crenulatus

LOs of Hebecysta, Heibergella, Noricysta and

excluding Sverdrupiella mutabilis

LO of Ricciisporites umbonatus

LO of common Limbosporites lundbladiae

LO of Aratrisporites

LO of taeniate bisaccate pollen

LO of Sverdrupiella mutabilis base of the Tuvalian (upper Carnian)

base of the Norian

base of the Norian

base of the Norian

base of the Norian

base of the Norian

base of the Norian

base of the Norian

base of the Norian

base of the Norian

base of the Norian

$50 \%$ up from the base of the Norian

$50 \%$ up from the base of the Norian

$50 \%$ up from the base of the Norian

$50 \%$ up from the base of the Norian

$50 \%$ up from the base of the Norian

base of the Rhaetian

base of the Rhaetian

$30 \%$ up from the base Rhaetian

base of the Jurassic

base of the Jurassic

base of the Jurassic

base of the Jurassic 


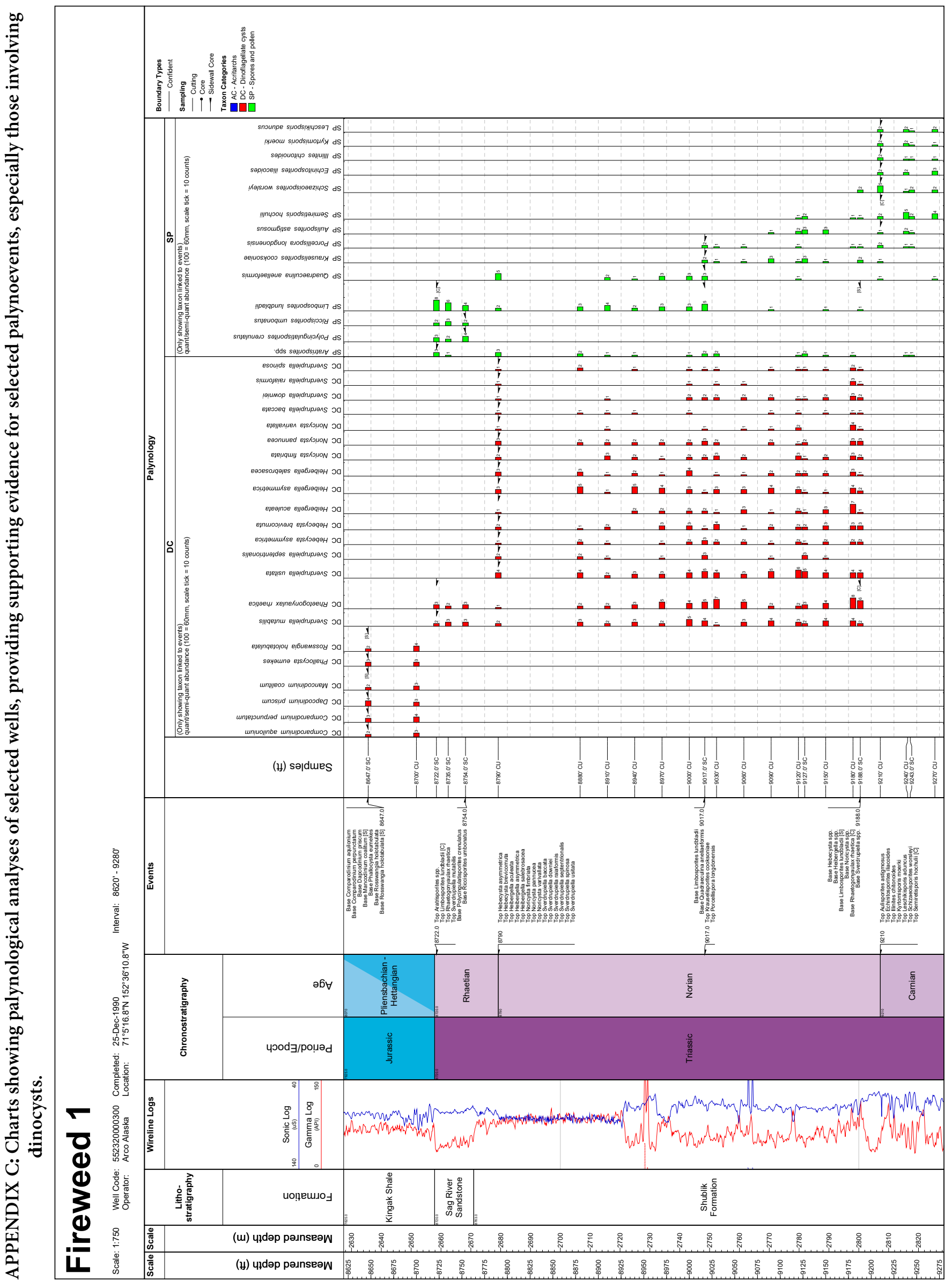




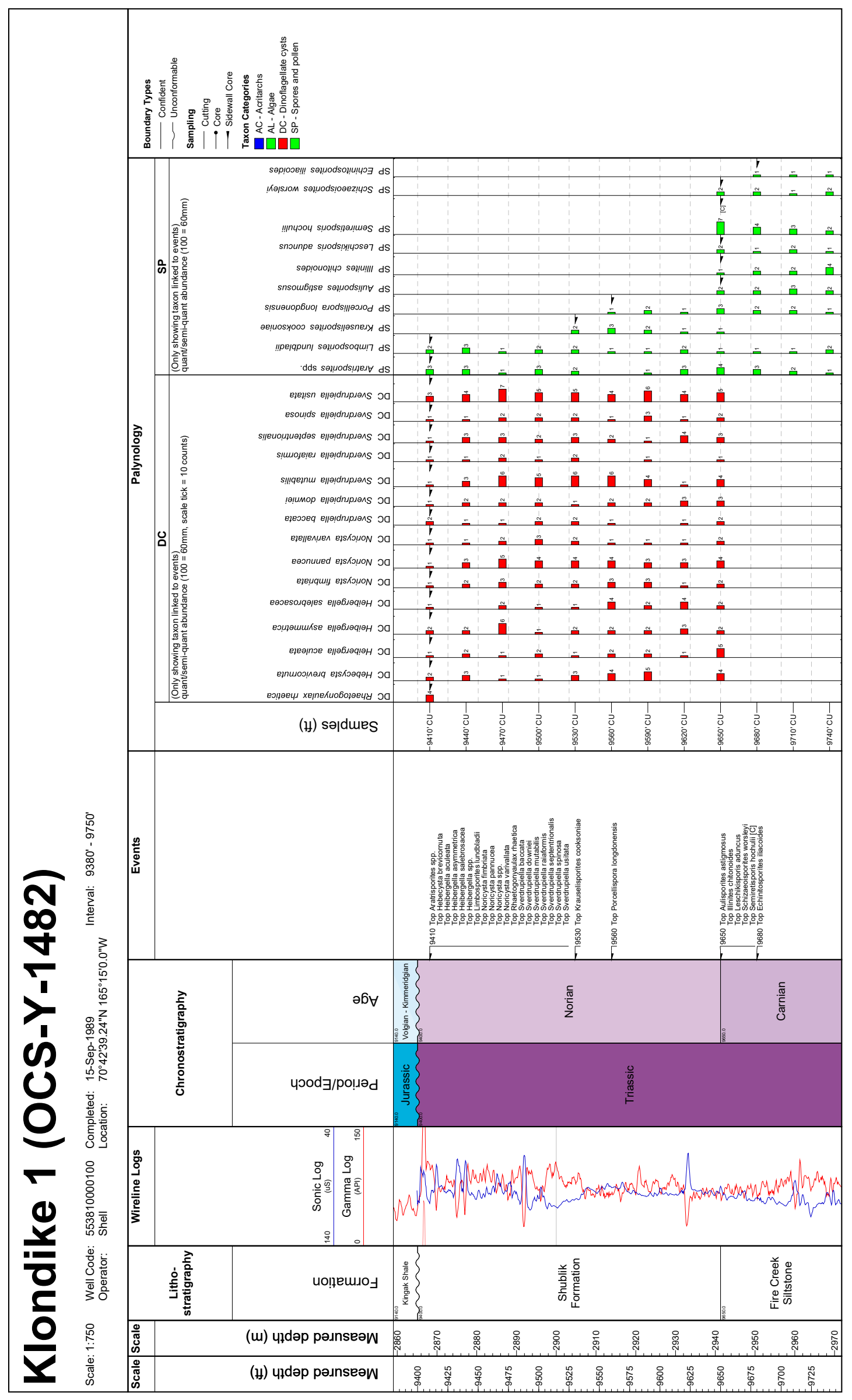




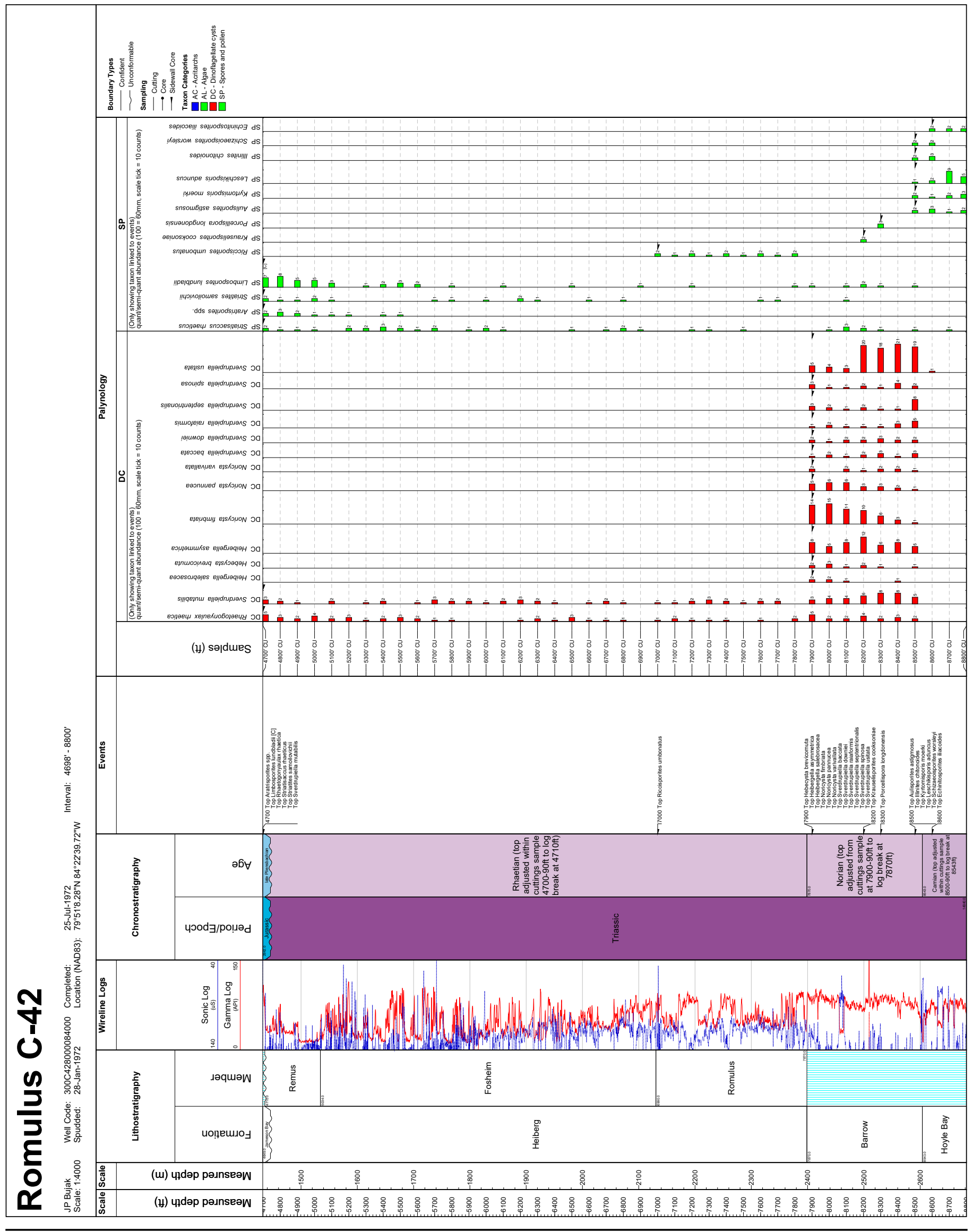

